\title{
Response of Sagebrush Carbon Metabolism to Experimental Precipitation Pulses
}

Authors: Bhaskar Mitra ${ }^{1}$, D. Scott Mackay ${ }^{1}$, Brent E. Ewers ${ }^{2,3}$, Elise Pendall ${ }^{2,3,4}$,

${ }^{1}$ Department of Geography, State University of New York at Buffalo, 105 Wilkeson Quadrangle, Buffalo, NY 14261, USA

${ }^{2}$ Department of Botany, University of Wyoming, 1000 E. University Avenue, Laramie, WY 82071, USA

${ }^{3}$ Program in Ecology, University of Wyoming, 1000 E. University Avenue, Laramie, WY 82071, USA

${ }^{4}$ Hawkesbury Institute for the Environment, University of Western Sydney, Australia

*Author to whom correspondence should be addressed:

Bhaskar Mitra

Email: bhaskar.mitra6@gmail.com

Phone: (001)8599483069

Date: 08/04/2016 


\section{List of Symbols:}

Abscisic acid concentration - ABA

Adenosine triphosphate - ATP

Air temperature $-T_{\mathrm{a}}$

Ambient carbon dioxide concentration $-C_{\mathrm{a}}$

Assimilated carbon (or Photosynthesis) $-A_{n}$

Assimilated carbon in the irrigated plots $-A_{\mathrm{i}}$.

Assimilated carbon in the non-irrigated plots $-A_{n i}$.

Autotrophic Respiration $-R_{\mathrm{a}}$

$\Delta A_{n}-A_{\mathrm{i}}-A_{n \mathrm{i}}$

Bayes information criteria - BIC

Carbon dioxide concentration $-\mathrm{CO}_{2}$

Day of year - DOY

Heterotrophic Respiration $-R_{\mathrm{h}}$

Isotope ratio measurements $-\delta^{13} C$

Isotope measurement of leaf-respired $\mathrm{CO}_{2}-\delta^{13} C_{\text {leaf }}$

Isotope measurement of leaf-respired $\mathrm{CO}_{2}$ in irrigated plot $-\delta^{13} C_{\mathrm{il}}$

Isotope measurement of leaf-respired $\mathrm{CO}_{2}$ in non-irrigated plot $-\delta^{13} C_{n i l}$

$\Delta \delta^{13} C_{1}-\delta^{13} C_{\mathrm{il}}-\delta^{13} C_{n i l}$

Isotope measurement of root-respired $\mathrm{CO}_{2}-\delta^{13} C_{\text {root }}$

Isotope measurement of root-respired $\mathrm{CO}_{2}$ in irrigated plot $-\delta^{13} C_{\mathrm{ir}}$ Isotope measurement of root-respired $\mathrm{CO}_{2}$ in non-irrigated plot $-\delta^{13} C_{n \text { ir }}$ $\Delta \delta^{13} C_{\mathrm{r}}-\delta^{13} C_{\mathrm{ir}}-\delta^{13} C_{n \mathrm{ir}}$ 
Isotope measurement of root-respired $\mathrm{CO}_{2}$ from trench plots $-\delta^{13} C_{\text {trench }}$

Leaf temperature $-T_{1}$

Predawn Water Potential $-\Psi_{\mathrm{pd}}$

Photosynthetically active radiation - PAR

Quantum yield $-\Phi_{\mathrm{PSII}}$

Quantum efficiency for light adapted leaves $-F_{\mathrm{v}}{ }^{\prime} / F_{\mathrm{m}}{ }^{\prime}$

Relative Humidity - RH

Ribulose-1,5-bisphosphate - RuBP

Soil Respiration $-R_{\mathrm{S}}$

Soil moisture in the respiration plots $-\theta_{\mathrm{s}}$

Soil moisture in the trench plots $-\theta_{\mathrm{h}}$

Stomatal conductance $-g_{\mathrm{s}}$

Temperature of the respiration plots $-T_{\mathrm{s}}$

Temperature of the trench plots $-T_{\mathrm{h}}$

Terrestrial Regional Ecosystem Exchange Simulator — TREES

Vapor pressure deficit $-D$

Vienna Pee Dee Belemnite — V-PDB

$W U E_{\mathrm{i}}$ - Water Use Efficiency 
Abstract

Effects of future large summer storm events due to climate change on vegetation carbon metabolism across western United States remains poorly understood. Canopy carbon metabolism of sagebrush (Artemisia tridentata) was evaluated for 7 days during the two driest months (July and August) by irrigating sagebrush plots with $20 \mathrm{~mm}$ precipitation pulses. Due to its dimorphic rooting system, we hypothesized sustained response to large precipitation events. Photosynthesis $\left(A_{\mathrm{n}}\right)$ and stomatal conductance $\left(g_{\mathrm{s}}\right)$ peaked within 2-3 days of irrigation and returned to preirrigation values by day 7 . Predawn water potential $\left(\Psi_{\mathrm{pd}}\right)$ peaked within 1 day and returned to its pre-pulse value by day 3 while potential quantum efficiency for light adapted leaves $\left(F_{\mathrm{v}}{ }^{\prime} / F_{\mathrm{m}}{ }^{\prime}\right)$ as well as intrinsic water use efficiency $\left(W U E_{\mathrm{i}}\right)$ was unresponsive. Unlike leaves, fine roots in the top $30 \mathrm{~cm}$ of soil were not a carbon sink. Heterotrophic respiration $\left(R_{\mathrm{h}}\right)$ was the dominant contributor to total soil respiration $\left(R_{\mathrm{S}}\right)$, and peaked within 24 hours before it dropped to pre-pulse value by day 3 . Different environmental drivers regulated $R_{\mathrm{s}}$ and $R_{\mathrm{h}}$, highlighting different kinetics of carbon production. Our study suggests ephemeral response of cold desert vegetation to future large summer storm events with important implications for the overall carbon storage capacity.

Keywords: Photosynthesis, Soil Respiration, Heterotrophic Respiration, Fine Roots, Carbon Metabolism 


\subsection{Introduction}

The Great Basin of western United States contains a large area of shrub cover $(\sim 60$ million hectares, Anderson and Inouye, 2001), which stores a significant amount of carbon, especially belowground (de Graaff et al., 2014). Snow remains the predominant form of precipitation across these regions while summer rainfall events are sporadic. Soil moisture recharge during the snow season not only favors the growth and development of woody species, but also allows it to sustain physiological activities during the summer (Ehleringer et al., 1991; Schenk and Jackson 2002; Ogle and Reynolds 2004). Most summer rain pulses across these regions are $\leq 5 \mathrm{~mm}$ (Loik et al., 2004) and they initiate microbial activity and photosynthetic response from shallow rooted plant species (Schwinning and Sala, 2004). Climate models predict dominant precipitation dynamics across these regions to shift from a winter to fall/spring regime, while summer precipitation is expected to show a reduction in storm frequency with a greater amount of rain per event under future scenarios of climate change (IPCC 2007) with potentially significant impacts on the overall carbon sequestration capacity across these regions.

Our overarching question is whether large summer storms (>15 mm, Schwinnning et al., 2003) can trigger lasting physiological responses in the plant-soil system? The focus on the response of vegetation to large events is necessary for three reasons: 1) It will trigger physiological responses from both aboveground and belowground plant process ; 2) Responses to a large event can help us design experiments to analyze productivity of vegetation to smaller rainfall events (Snyder et al., 2004); 3) From the perspective of climate change, a few large rainfall events in the future could be the difference between 'wet' and 'dry' years (Schwinning et al., 2003). Predicting vegetation responses to large summer storm events across semi-arid ecosystems in general remains complex because threshold-type responses are modulated by plant 
architecture, soil texture, and soil nutrient conditions (Huxman et al., 2004a; Potts et al., 2006a, b).

Extensive analyses at plant scale (e.g., Lauenroth et al., 1987; Cui and Caldwell 1997; Dougherty et al., 1996; Golluscio et al., 1998; BassiriRad et al., 1999; Gebauer and Ehleringer 2000; Schwinning et al., 2002) have provided insight with regard to the response of vegetation across semi-arid ecosystem to large summer experimental pulses. These studies have either used a combination of isotope analysis, sap flow, gas exchange measurements, soil water content or respiration to analyze the impact of simulated rainfall events on vegetation productivity. But simultaneous measurements of the three key processes - carbon assimilation, allocation and respiration - that regulate productivity at plant scale remain scarce. Measuring these processes together is important because the timing of photosynthesis and respiration responses to large precipitation pulses during summer has implications for the carbon storage capacity of dryland ecosystems as well as overall impact on plant community dynamics. Recent assessment of carbon exchange across cold-desert shrub ecosystems has found high intensity summer storm events lead to disproportionate increase in ecosystem respiration compared to photosynthesis, while small storm events facilitate the carbon sink behavior of the biome (Xie et al., 2015), both of which may be modulated by the spring moisture received by deep roots (Kwon et al., 2008). Ecological manipulation experiments that analyze the vulnerability of these key processes to large precipitation pulses can provide additional mechanistic insights into arid land carbon metabolism (Jentsch et al., 2007; Chen et al., 2009).

$A_{\mathrm{n}}$ is a robust metric to quantify carbon assimilation as it encompasses a broad range of a plant's physiological activities. For pulse-driven ecosystems, however, extensive periods of dry conditions during summer may impair the carbon uptake capacity of the plant in response to 
large precipitation (Flexas et al., 2002; Grassi and Magnani, 2005; Flexas et al., 2006).

Therefore, apart from $A_{\mathrm{n}}$, a mosaic of metrics, including $\Psi_{\mathrm{pd}}, g_{\mathrm{s}}$, and quantum efficiency for light-acclimated leaves $\left(F_{\mathrm{v}}{ }^{\prime} / F_{\mathrm{m}}{ }^{\prime}\right)$ need to be analyzed to provide a comprehensive understanding of the role of a priori drought stress in regulating the carbon assimilation capacity of the vegetation including stomatal and non-stomatal regulation of $A_{\mathrm{n}}$ (Davis and Mooney, 1986; Maxwell and Johnson, 2000; Yan et al., 2000; Maestre et al., 2005). Another important metric to quantify change in vegetation productivity in response to variation in precipitation pulses is intrinsic water use efficiency $\left(W U E_{\mathrm{i}}\right) . W U E_{\mathrm{i}}$ is a function of plant genetics as well as the environment (Garten and Taylor, 1992; Zhang et al., 1993; Lauteri et al., 1997). While the metric can be measured at several scales, $W U E_{\mathrm{i}}$, measured at leaf level and defined as the ratio of $A_{\mathrm{n}} /$ $g_{\mathrm{s}}$, is of particular interest to quantify the physiological acclimation to changes in water stress and is strongly induced by stomatal control (Bierhuizen \& Slatyer, 1965; Galmes et al., 2011; Zegada-Lizarazu et al., 2011).

For dryland vegetation to benefit from a precipitation pulse either it must have active roots, or it must quickly reestablish root activity (BassiriRad et al., 1999). Previous studies on shrubs in the Great Basin have found a decline in root activity during the late summer (Holthausen and Caldwell, 1980; Carbone and Trumbore, 2007). For non-forest ecosystems in general, dynamics of fine root biomass $(<2 \mathrm{~mm}$ in diameter) in the upper $30 \mathrm{~cm}$ of soil is critical in modulating the overall productivity (Barbosa et al., 2012). An improved understanding of fine root turnover remains a hindrance for predicting vegetation productivity in a changing climate (Norby and Jackson, 2000). Hence, linking carbon allocation to fine roots will be key to understanding the response of vegetation to large precipitation pulses. A strong link between photosynthesis and root activity has already been established for grassland (Craine et al., 1998; 
Johnson et al., 2002) and forest ecosystems (Hogberg et al., 2001; Irvine et al., 2005; Liu et al., 2006), but semi-arid shrublands remain understudied.

Total soil respiration $\left(R_{\mathrm{s}}\right)$, another critical component of the carbon balance, originates from roots $\left(R_{\mathrm{a}}\right.$, autotrophic) and microbes $\left(R_{\mathrm{h}}\right.$, heterotrophic). Separate analysis of the response of $R_{\mathrm{h}}$, as well as its sensitivity to moisture and temperature is crucial as this provides information about the response of microbial decomposition processes to an altered precipitation regime. $R_{\mathrm{h}}$ should be analyzed separately because it has different responses to temperature, moisture and substrate availability compared to autotrophic respiration (Bond-Lamberty et al., 2004). Improving scientific understanding of the response of heterotrophic respiration to soil moisture and temperature is also critical to improving forecasts of soil respiration responses in dryland ecosystems to climate change (Lavigne et al., 2004).

Drought tolerant sagebrush (Artemisia tridentata), one of the most common Great Basin perennial shrubs, has key traits that allow it to survive in arid ecosystems (Flanagan et al., 1992). Sagebrush has both active shallow and deep roots that extend at least to 2-m depth (Richards and Caldwell, 1987). Extensive movement of soil water between the shallow and deep layers, also known as hydraulic redistribution (Richards and Caldwell, 1987) allows sagebrush to sustain physiological activities during the summer. On account of its active shallow root distribution as well as active foliage area we anticipate that sagebrush will have the capacity to utilize large summertime precipitation pulses. As precipitation pulses greater than $15 \mathrm{~mm}$ are categorized as large precipitation pulse across the Great Basin of Western United States (Ivans et al., 2003), the following hypotheses were tested to analyze the response of aboveground and belowground plant processes to a $20 \mathrm{~mm}$ pulse:

- Hypothesis 1 - Large precipitation events during summer result in sustained 
increases in photosynthesis in sagebrush.

- Hypothesis 2 - Fine roots of sagebrush carry the isotopic signature of recently assimilated carbon.

- Hypothesis 3 - Different environmental drivers regulate soil $\left(R_{\mathrm{S}}\right)$ and heterotrophic respiration $\left(R_{\mathrm{h}}\right)$ during different times across the summer season in response to a large precipitation pulse.

\subsection{Methods and Analysis}

Study Site

An irrigation experiment was conducted near Saratoga, Wyoming (Latitude $=41.45^{\circ}$, Longitude $=-106.81^{\circ}$, Elevation $=2173 \mathrm{~m}$ asl) in July and August in 2009. The research site had near-level topography (<1\% slope) and sandy loam soils. Mean annual temperature and precipitation were $7.1^{\circ} \mathrm{C}$ and $32.7 \mathrm{~cm}$ at Rawlins $(\sim 70 \mathrm{~km}$ from Saratoga and at the same elevation; 30-year means from 1980-2009) (www.wrcc.dri.edu). Mean temperature in 2009 was $4.9^{\circ} \mathrm{C}$ and precipitation was $25.8 \mathrm{~cm}$. July and August are historically the driest months and this was also true in 2009 (www.wrcc.dri.edu) (Figure Appendix A1A \& A1B). Over 95\% of JulyAugust precipitation events were less than $5 \mathrm{~mm}$ (Figure Appendix A1C). Total vegetation cover at the study area near Saratoga was about $37 \%$ with relative vegetation cover of Wyoming big sagebrush (Artemisia tridentata ssp. wyomingensis) of 17.6\% (Mitra et al., 2014). The site also supported perennial grasses (e.g., Festuca idahoensis and Poa secunda, Koeleria macrantha) and forbs (e.g., Eriogonum umbellatum, Phlox spp.).

Experiment Overview

Physiological responses of sagebrush shrubs and associated fluxes of $R_{\mathrm{s}}$ and $R_{\mathrm{h}}$ to pulse precipitation events were analyzed for 7 days following each of two experimental irrigations, one 
in July and one in August. There were two treatments (irrigated \& non-irrigated) with three replications for each treatment. The irrigation treatments were conducted on $1 \mathrm{~m}^{2}$ plots that encompassed a single sagebrush plant, separated by more than $2 \mathrm{~m}$ to prevent spatial autocorrelation and interaction between plots (Ewers and Pendall, 2008; Mitra et al., 2014).

We employed the trench method to analyze $R_{\mathrm{h}}$ (Hanson et al., 2000), whereby a trench $0.5 \mathrm{~m}$ deep was excavated outside of the plot $\left(1 \mathrm{~m}^{2}\right)$ in the third week of June. At $0.5 \mathrm{~m}$ depth, the trenches were below the main rooting zone (Cleary et al., 2010). A layer of water permeable, root barrier fabric was installed and the trenches were backfilled. In order to prevent the flow of aboveground carbon to the roots and rhizosphere, we sprayed herbicidal treatment ( $2 \%$ Glyphosate) on the leaves. After the plants died, they were cut at the root crowns and then removed. This treatment was done three weeks prior to the first irrigation experiment.

We exposed the plants to large summer precipitation event by simulating two $20-\mathrm{mm}$ rainfall events, one in July and one in August, in order to trigger physiological response from plants, soil and microbes. Water was applied evenly and slowly above the irrigated sagebrush and trench plots in order to ensure there was no surface runoff. Our method of water addition was similar to the method used in previous irrigation experiments (Gebauer et al., 2002; Ivans et al., 2003; Loik 2007). Predawn water potential, photosynthesis, soil and heterotrophic respiration and carbon isotope ratio measurements were initiated one day prior to the irrigation experiment (day -1) and then repeated on days one, three, five and seven following the irrigation treatment (Table 1). Measurement time period for the sagebrush and trench plots have been summarized in Table 1 and DOY for the irrigation in July and August have been highlighted in Figure A2 (Appendix). 
Leaf Level Measurements

$\Psi_{\text {pd }}$ quantifies antecedent water stress and was measured using a pressure chamber (PMS Instruments, Albany, OR, USA) on two stems (2-3 mm diameter) in each of the six plots. We measured $g_{\mathrm{s}}, A_{\mathrm{n}}$, quantum yield ( $\left.\Phi_{\mathrm{PSII}}\right)$, and $F_{\mathrm{v}}{ }^{\prime} / F_{\mathrm{m}}{ }^{\prime}$ with an open path gas exchange system (LI6400XT, LI-COR, Inc., Lincoln, NE) integrated with a fluorescence chamber head (LI-6400-40 leaf chamber fluorometer; LI-COR, Inc., Lincoln, NE). The measurements were conducted between 9.00 - 12.00 local time one day prior to the irrigation experiment (day -1) and then repeated on days one, three, five and seven following irrigation (Table 1). A red-blue light source attached to the gas exchange system was used to illuminate the leaves, while controlling for vapor pressure deficit $(\mathrm{D})$, air temperature $\left(T_{a}\right)$, photosynthetically active radiation (PAR), and ambient carbon dioxide concentration $\left(C_{\mathrm{a}}\right)$ concentration in the chamber. Prior to gas exchange measurements, leaves kept inside the chamber were allowed to reach steady-state photosynthesis at ambient $C_{\mathrm{a}}(360 \mathrm{ppm})$, leaf temperature $\left(T_{1}\right)\left(26^{\circ} \mathrm{C}\right)$ and at saturating PAR conditions (1600 $\mu \mathrm{mol} \mathrm{m} \mathrm{m}^{-2} \mathrm{~s}^{-1}$. The range of $D$ was $1-3 \mathrm{kPa}$ to replicate the changing environmental conditions in the field. All measurements were conducted on a minimum of 3 leaves per plot. After the measurements were conducted, leaves were brought back to the laboratory for leaf area analysis. The leaves were first scanned and then leaf areas were calculated using Image-J software (http://rsb.info.nih.gov/ij).

Soil Respiration Measurement

To measure soil respiration, an EGM-4 IRGA with an SRC-1 soil respiration chamber (PP Systems International, Inc., Amesbury, MA, USA) was used. At each of 12 plots (3 irrigated shrub, 3 non irrigated shrub, 3 irrigated trench and 3 non irrigated trench), respiration was measured at the center and periphery of the plot. $R_{\mathrm{S}}$ was measured on intact plots while $R_{\mathrm{h}}$ was 
measured on trenched plots. Adjacent to the respiration measurement points, soil temperature $\left({ }^{\circ} \mathrm{C}\right)(\mathrm{HI} 9053$, Hanna Instruments, Smithfield, RI, USA) and volumetric soil moisture (HH2 Moisture Meter; delta - T Devices, Cambridge, England) were measured at $0.06 \mathrm{~m}$ depth. Isotope Measurements

Field sampling of the leaf respired $\mathrm{CO}_{2}, \delta^{13} C_{\text {leaf }}$, and root respired $\mathrm{CO}_{2}, \delta^{13} C_{\text {root }}$, for the sagebrush plot and root respired $\mathrm{CO}_{2}$ for the trench plot, $\delta^{13} C_{\text {trench, were conducted between }}$ 13.00-15.00 hours on all experimental days. Carbon isotope analyses of the leaves were conducted in order to examine whether leaves were strong carbohydrate sinks and whether they competed with roots for carbon allocation. Large-bore syringes of $60 \mathrm{ml}$ capacity were used to collect leaf and root respired $\mathrm{CO}_{2}$ from the sagebrush plots and roots from the trench plots. Fine roots (diameter $<2 \mathrm{~mm}$ ) were collected and washed with water to remove soil particles. For each plot, root samples were composited into a single sample of about $0.5 \mathrm{~g}$ fresh weight and placed inside the syringe barrel and flushed with $\mathrm{CO}_{2}$-free air. A similar procedure was applied for the leaf samples. The syringe samples containing the leaves were covered with aluminum foil to prevent photosynthesis. $\mathrm{CO}_{2}$ inside the syringe barrels was allowed to accumulate for 40 minutes in the dark at ambient temperature and then $15 \mathrm{ml}$ of the air was collected in pre-evacuated vials, which were sent to the University of Wyoming Stable Isotope facility (www.uwyo.edu/sif) for $\delta^{13} \mathrm{C}$ analysis by Thermo Finnigan Gas Bench in line with a Finnigan Delta Plus XP (Thermo Finnigan, Bremen, Germany). $\delta^{13} \mathrm{C}$ values were reported in \%o with respect to Vienna Pee Dee Belemnite (V-PDB). Instead of reporting absolute values, change in $\delta^{13} C_{\text {leaf }}, \delta^{13} C_{\text {root }}$ and

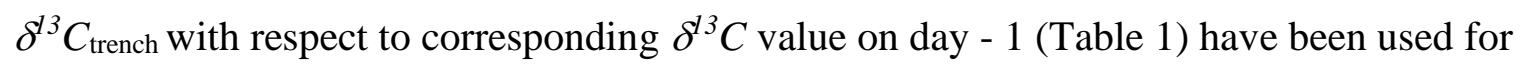
analysis. Measurement time periods for the sagebrush and trench plots are summarized in Table 
1, and day of year (DOY) for the irrigation in July (DOYs 194 - 202) and August (DOYs 229 238) are shown in relation to natural precipitation in Figure A2 (Appendix).

Modeled Carbon Assimilation $\left(A_{\mathrm{n}}\right)$

We modeled carbon assimilation in response to precipitation pulses with the Terrestrial Regional Ecosystem Exchange Simulator (TREES) (Mackay et al., 2003; Samanta et al., 2007; Loranty et al., 2010). The objective of modelling carbon assimilation from day -1 to day 7 was to assess the impacts of precipitation on the time-integrated carbon accumulation process. TREES solved for $A_{\mathrm{n}}$ for each of the experimental days at 30-minute time steps using the Farquhar model (Farquhar et al.1980; Farquhar and von Caemmerer, 1982; de Pury and Farquhar, 1997) coupled to a simple plant hydraulic model (Katul et al., 2003). Environmental data to run TREES were obtained from an adjacent meteorological station. PAR (LI-190SZ, LI-COR Inc.), $T_{\mathrm{a}}$ and relative humidity $(R H)$ (HMP45C, Vaisala, Helsinki, Finland) were monitored at a height of $2.5 \mathrm{~m} . g_{\mathrm{s}}$ and $\Phi_{\mathrm{PSII}}$ obtained from leaf-level measurements were used to constrain the photosynthesis subroutine of TREES. The remaining photosynthesis parameters were constrained based on light response curves measured on a similar sagebrush subspecies (A. tridentata var vaseyana) at Sierra Madre Mountain Range, Wyoming (Naithani 2009).

Data Analysis

Since each plot was an experimental unit, measurements were averaged by plot for analysis. A repeated measures ANOVA was used to test for effects of time and treatment on $\Psi_{\mathrm{pd}}, g_{\mathrm{s}}, A_{n}, \Phi_{\mathrm{PSII}}, F_{\mathrm{v}}{ }^{\prime} / F_{\mathrm{m}}{ }^{\prime}, \delta^{13} C_{\text {leaf }}, \delta^{13} C_{\text {root }}, \delta^{13} C_{\text {trench }}, W U E_{\mathrm{i}}, R_{\mathrm{s}}, R_{\mathrm{h}}$, soil moisture of the respiration $\left(\theta_{\mathrm{s}}\right)$ and trench plots $\left(\theta_{\mathrm{h}}\right)$ as well as soil temperature of the respiration $\left(T_{\mathrm{s}}\right)$ and trench plots $\left(T_{\mathrm{h}}\right)$. Time was considered as a within-subjects factor, whereas treatment (irrigated versus non- irrigated) was a between subjects factor. Wherever we found a significant effect of 
treatment, we used unpaired t-tests to compare the mean for any of the measured variables between the irrigated and non-irrigated plots. In repeated measures ANOVA, degrees of freedom were corrected whenever Mauchly's test indicated that the assumption of sphericity was violated. Deviation from the assumption of sphericity was estimated by epsilon ( $\varepsilon$ ). Huynh-Feldt correction was applied when $\varepsilon$ was $>0.75$ and Greenhouse-Geisser correction was applied when $\varepsilon$ was $<0.75$ (Girden 1992).

We used a mixed modelling approach to analyze relationship between respiration, moisture, temperature, and time. We incorporated nonlinear effects as well as temperaturemoisture interactions on account of the complex multiple pathways originating from roots, litter and rhizosphere that regulate respiration. Our mixed-modeling exercise involved a top-down strategy which can be summarized as follows: 1) Selected the fixed effects of the covariates including interactions; 2) Selected a structure of the random effects and 3) covariance structure of the model residuals. In steps $2 \& 3$, we used REML-based likelihood ratio tests to determine the optimum random as well as the model residual structure. 4) Finally we reduced the model by removing the fixed effects parameters which were not significant at $\alpha=0.05$ level. We selected the model with the lowest Bayes information criteria (BIC).

Irrigation effects on the isotope values of the leaves and fine roots in both July and August were calculated as the difference between the isotope value of leaf (or roots) on irrigated and non-irrigated plots ( $\Delta \delta^{13} \mathrm{C}_{1}$ for leaves and $\Delta \delta^{13} \mathrm{C}_{\mathrm{r}}$ for roots). On each measurement day, we evaluated correlations of $\Delta \delta^{13} \mathrm{C}_{1}$ and $\Delta \delta^{13} \mathrm{C}_{\mathrm{r}}$ with the net photosynthetic difference $\left(\Delta A_{\mathrm{n}}\right)$ between the total assimilated carbon between the irrigated $\left(A_{\mathrm{i}}\right)$ and non-irrigated plots $\left(A_{n \mathrm{i}}\right) . A_{\mathrm{i}}$ and $A_{n \mathrm{i}}$ were calculated using the TREES model. The objective of correlation analysis was to assess whether change in isotope values of the roots and leaves bore the fingerprint of carbon 
assimilated in response to the pulse of moisture. Since samples for $\delta^{13} C$ analysis were collected between 13.00-15.00 hours, $\Delta A_{\mathrm{n}}$ was lagged by $0,+3,+6$ and +9 hours with respect to $15: 00$ hours.

Unless otherwise noted, mean values were reported followed by standard errors. Statistical analyses were tested for significance at $\mathrm{p}<0.05$ level. All statistical analyses were conducted using R (version 2.15.2, R Development Core Team, 2007) and PASW Statistics 18 (formerly SPSS). Since we did not construct rain-out shelters, any precipitation event between the two irrigation experiments influenced both the irrigated and non-irrigated plots.

\subsection{Results}

Prior to irrigation, $\theta_{\mathrm{s}}$ was lower in July (Figure 1A; $3 \%$ ) compared to August (Figure $1 \mathrm{~B} ; \sim 6 \%$ ). With respect to soil moisture on day $-1, \theta_{\mathrm{s}}$ increased by nearly $120 \%$ (Figure $1 \mathrm{~A}$ ) and $241 \%$ (Figure 1B) in irrigated plots on day 1 in July and August respectively. There were significant effects of treatment as well as time $\mathrm{x}$ treatment interaction in both months (Table 2). Significant differences between the two treatments were evident in both months on days 1 and 3 and only on day 5 in July (Figures $1 \mathrm{~A}-\mathrm{B}$, t-test $\mathrm{p}<0.05$ ). Unlike soil moisture, we only found a significant effect of time for $T_{\mathrm{s}}$ for both months (Figures 1C-D, Table 2).

In the trench plots, significant effects of time, treatment and their interaction were observed for $\theta_{\mathrm{h}}$ in both the months (Table 2), with $\theta_{\mathrm{h}}$ on days 1,3 and 5 being statistically different from each other (Figures $1 \mathrm{E}-\mathrm{F}$ ). $T_{\mathrm{h}}$ in the trench plots were significantly different between the two treatments only in July (Figure 1G, t-test $\mathrm{p}<0.05$ ).

The response of $A_{\mathrm{n}}$ (Figures 2A-B) and $g_{\mathrm{s}}($ Figures 2E-F) to irrigation was similar in both months. However, we found a significant effect of treatment only in August (Table 2), on days 1 $\left(A_{n} \& g_{\mathrm{s}}\right), 3\left(A_{n} \& g_{\mathrm{s}}\right)$ and $5\left(g_{\mathrm{s}}\right)$ (Figures 2B \& 2F). Prior to pulse treatment (day -1), sagebrush 
predawn water potential was lower in August $\left(\Psi_{\mathrm{pd}} \sim-5 \mathrm{MPa}\right)$ compared to July $\left(\Psi_{\mathrm{pd}} \sim 3.5 \mathrm{MPa}\right)$ (Figures 2C -D). In both months, $\Psi_{\mathrm{pd}}$ increased on day 1 compared to day -1 , followed by a gradual decline. There were significant effects of time and time $\mathrm{x}$ treatment interaction on $\Psi_{\mathrm{pd}}$ in both July and August and of treatment in August (Table 2). Significant $\Psi_{\text {pd }}$ differences in August were evident on days 1 and 3 (Figure 2D). We found significant time and time x treatment interactions in the responses of $F_{\mathrm{v}}{ }^{\prime} / F_{\mathrm{m}}{ }^{\prime}$ (Figures $\left.2 \mathrm{G}-\mathrm{H}\right)$ and $\Phi_{\mathrm{PSII}}$ (Figures not shown) to pulse inputs in both July and August (Table 2). Average $W U E_{\mathrm{i}}$ (shown as numbers) did not show any trend in response to irrigation (Figures $2 \mathrm{E} \& 2 \mathrm{~F}$ ). R-ANOVA analysis also did not reveal any significant effects of time, treatment or both in July and August (Table 2). We also found no significant correlation between the absolute values of $\delta^{13} C_{\text {leaf }}\left(\& \delta^{13} C_{\text {root }}\right)$ and $W U E_{\mathrm{i}}$ (not shown) in July or August. $A_{\mathrm{n}}$ was not significantly correlated with either $\Psi_{\mathrm{pd}}($ Figures $3 \mathrm{~A}-\mathrm{B})$ or $F_{\mathrm{v}}{ }^{\prime} / F_{\mathrm{m}}{ }^{\prime}$ (Figures 3C - D) in July or August. However, $A_{\mathrm{n}}$ and $g_{\mathrm{s}}$ were strongly correlated in August $\left(r^{2}=0.93, p<0.05\right.$, Figure 3F).

No significant treatment or interactive effects were observed for the changes in $\delta^{13} C_{\text {leaf }}$ (Figures 4A-B), $\delta^{13} C_{\text {root }}$ (Figures $4 \mathrm{C}-\mathrm{D}$ ) or $\delta^{13} C_{\text {trench }}$ (Figures $4 \mathrm{E}-\mathrm{F}$ ) (Table 2). But in July there was a significant effect of time for changes in $\delta^{13} C_{\text {leaf }}$ (Table 2). Statistically significant correlation $(\mathrm{p}<0.05)$ between $\Delta A_{n}$ and $\Delta \delta^{13} C$ were observed for leaves in August for lag periods corresponding to 0 and 3 hours (Table 3 ). No trend was observed for lag periods corresponding to 6 and 9 hours. In case of fine roots, we found no significant correlation in both the months (Table 3).

While $R_{\mathrm{s}}$ (Figures 5A \& B) peaked within 24 hours after pulse application in both months, a significant difference between the two treatments existed only in August (Table 2). $R_{\mathrm{S}}$ values were significantly different between the two treatments on days 1, 3, 5 and 7 in August 
(Figure 5B). While the response trend for $R_{\mathrm{h}}$ was similar to $R_{\mathrm{S}}$, we found no significant time, treatment or interaction effects (Figures $5 \mathrm{C} \& \mathrm{D}$, Table 2). We also found no significant relationship between $R_{\mathrm{s}}$ and $\Psi_{\mathrm{pd}}$ either in July or August (Figures 6A \& B).

In July, $R_{\mathrm{s}}$ was negatively correlated with $T_{\mathrm{s}}$ but positively correlated with $\theta_{\mathrm{s}}$ (Table 4 ). In August, both the main effects of $T_{\mathrm{s}}$ and $\theta_{\mathrm{s}}$ negatively influenced respiration while the main effects of $\theta_{\mathrm{s}}^{2}$ and $T_{\mathrm{s}} \mathrm{x} \theta_{\mathrm{s}}$ interaction were weak positive drivers of soil respiration. $\theta_{\mathrm{h}}$ was negatively correlated with $R_{\mathrm{h}}$ in both months (Table 4 ). $\theta_{\mathrm{h}}{ }^{2}$ and $T_{\mathrm{h}} \mathrm{x} \theta_{\mathrm{h}}$ interaction were weak positive drivers of heterotrophic respiration in July and August respectively. $R_{\mathrm{h}}$ also significantly decreased with time in August (Table 4).

\subsection{Discussion}

Hypothesis 1 - Large precipitation events during summer will result in sustained increase in photosynthesis in sagebrush.

Contrary to our hypothesis, increase in $A_{n}$ (Figures $2 \mathrm{~A}-\mathrm{B}$ ) as well as $g_{\mathrm{s}}($ Figures $2 \mathrm{E}-\mathrm{F})$ did not last beyond three days. A temporary increase in soil moisture (Figs. 1A-B) at 0-6 cm zone suggests that either there could have been rapid downward percolation of water to deeper soil layers for later use $(30-50 \mathrm{~cm})$, high fraction of moisture may have left the soil as evaporation or there could have been hydraulic redistribution by roots (Naithani et al., 2012). Isotopically labeled water was not applied to the shrubs to identify the extent of moisture utilization from the shallow and deep roots. We speculate that the increase in $A_{\mathrm{n}}$ was ephemeral because sagebrush primarily absorbed moisture from the shallow soil layer $(0-6 \mathrm{~cm})$ during this time frame (Schwinning et al., 2003).

We believe lack of any response in the soil temperature in the irrigated plots (compared to non -irrigated plots) even on day 1 (Figs. 1C-D) may be linked to plant shade and not vegetation 
productivity. The small duration of increase in $\Psi_{\mathrm{pd}}$ suggests lack of adequate fine roots for moisture uptake in response to application of precipitation (Figs 2C-D) (Flanagan et al., 1992). $\Psi_{\text {pd }}$ reflects the amount of moisture available in the rhizosphere and has been widely used by researchers as an indicator to assess plant water stress including response to irrigation (Resco et al., 2008).

The delayed response of $g_{\mathrm{s}}$ (Figure 2E, peak value on day 3), can be attributed to the time required by water to reach photosynthetic chlorenchyma to initiate $\mathrm{CO}_{2}$ assimilation. Probable secondary reasons include leakage of solute from guard cells (Ehret and Boyer, 1979; Yan et al., 2000) and increase in abscisic acid (ABA) concentration (Henson et al., 1984; Yan et al., 2000). We eliminate the possibility of fine root growth modulating the delayed response on account of the ephemeral increase in $A_{\mathrm{n}}$ as nutrients associated with increase in soil moisture does not appear to be available for plant acquisition.

Lack of significant changes (Table 2) in WUEi between irrigated and non-irrigated plots was consistent with other studies (Miyashita et al., 2005; de Souza et al., 2005). WUE $E_{\mathrm{i}}$ is strongly induced by changes in environmental conditions. Despite the application of $20 \mathrm{~mm}$ precipitation pulse, we found large changes in soil moisture conditions only for twenty-four hours. This probably accounted for the lack of significant time as well as treatment effect with regard to $W U E_{\mathrm{i}}$. Moreover, our $W U E_{\mathrm{i}}$ estimation was based on instantaneous gas exchange measurements in the morning. On account of high spatial and temporal heterogeneity of $A_{\mathrm{n}} / g_{\mathrm{s}}$ and lack of strong correlation (results not shown) between $W U E_{\mathrm{i}}$ and $\delta^{13} \mathrm{C}_{1}\left(\& \delta^{13} \mathrm{C}_{\mathrm{r}}\right)$, it remains uncertain the extent to which our measurement is representative of whole plant level $W U E_{\mathrm{i}}$ (Medrano et al., 2015). A time-integrated assessment of $W U E_{\mathrm{i}}$ can be used with greater confidence as a selection criterion to quantify response of plant to changes in precipitation intensity and can be better linked to isotopic discrimination (Guehl et al., 1995) 
Lack of significant correlation between $\Psi_{\mathrm{pd}}$ and $A_{\mathrm{n}}$ indicates that wetting of the soil and microbes is a much faster process than carbon uptake (Figures 3A \& B, Huxman et al., 2004b; Resco et al., 2008). Significant correlation between $A_{n}$ and $g_{\mathrm{s}}$ (Figure 3F) indicates stomatal regulation of photosynthesis in sagebrush in August. Lack of correlation in July indicates possible biochemical limitations apart from stomatal regulation modulating the carbon assimilation process (Yan et al., 2000; Pockman and Small, 2010). On account of lack of photosynthesis versus intercellular $\mathrm{CO}_{2}$ concentration measurements before and after irrigation treatment, the weak correlation between $A_{\mathrm{n}}$ and $F_{\mathrm{v}}{ }^{\prime} / F_{\mathrm{m}}{ }^{\prime}($ Figures $3 \mathrm{C} \& \mathrm{D})$ itself does not provide any evidence of the nature of metabolic processes limiting carbon uptake. Possible multiple factors modulating the weak correlation between $A_{\mathrm{n}}$ and $F_{\mathrm{v}}{ }^{\prime} / F_{\mathrm{m}}{ }^{\prime}$ include production of ascorbic acid, epoxidation of carotenoid pigments ( $\mathrm{Lu}$ and $\mathrm{Lu}, 2004)$, increased dissipation of nonphotochemical excitation energy (Maxwell and Johnson, 2000) and photoinhibitory damage at the photosystem II reaction centers (Valladares and Pearcy, 1997; Maxwell and Johnson, 2000). Researchers have argued that response of $F_{\mathrm{v}}{ }^{\prime} / F_{\mathrm{m}}{ }^{\prime}$ across vegetation in semi-arid ecosystems is also a function of the intensity of precipitation pulse and as well as the duration of inter-pulse period (Resco et al., 2008). Weak correlation between $A_{\mathrm{n}}$ and $F_{\mathrm{v}}{ }^{\prime} / F_{\mathrm{m}}{ }^{\prime}$ could therefore be attributed to the different time-lags in the response of $A_{\mathrm{n}}$ and $F_{\mathrm{v}}{ }^{\prime} / F_{\mathrm{m}}{ }^{\prime}$ to large precipitation pulses.

Overall, the different time lags of $\Psi_{\mathrm{pd}}$ and $A_{\mathrm{n}}$ in response to irrigation and lack of any response of $F_{\mathrm{v}}{ }^{\prime} / F_{\mathrm{m}}{ }^{\prime}$ highlights the need to exercise caution in using $\Psi_{\mathrm{pd}}$ and $F_{\mathrm{v}}{ }^{\prime} / F_{\mathrm{m}}{ }^{\prime}$ as metrics of stress on biological activity in pulse-driven ecosystems (Resco et al., 2008). Our results are consistent with prior research showing that desert vegetation in Western North America is often unresponsive to large precipitation pulses (Schwinning et al., 2002; Schwinning et al., 2005). Researchers have attributed multiple factors including nutrient constraint (Snyder et al., 2004) as 
well as root embolism in constraining the response to precipitation (Kolb and Sperry, 1999; Sperry_and Hacke, 2002). Many researchers have argued that the conservative response of desert plants to summer precipitation should be viewed from the perspective of energetic requirements for vegetation (Ehleringer and Pearcy, 1983). From a cost-benefit analysis perspective, two 20 $\mathrm{mm}$ pulses were probably not sufficient to cross the threshold to allow sustained carbon investment (Comstock and Ehleringer, 1986; Schwinning et al., 2003).

It seems unlikely that a higher precipitation pulse $(>20 \mathrm{~mm})$ would have induced a different response in photosynthesis or stomatal conductance. Rainfall manipulation experiments in sagebrush vegetation yielded similar response pattern in photosynthesis and stomatal conductance in response to a $46 \mathrm{~mm}$ precipitation pulse (Loik 2007). Researchers have attributed the suppressed carbon assimilation capacity of desert species to multiple complex interactions between root depth, soil nitrogen content, thermal stress, antecedent soil moisture conditions and general reliance on winter precipitation (Loik 2007; Kwon et al., 2008). Our study provides strong evidence to support this knowledge base.

Significant increase in photosynthesis and stomatal conductance of sagebrush in August may be attributed to changes in leaf morphology. Though we did not monitor phenological development as a function of DOY, previous research work have shown that sagebrush shed their ephemeral leaves in July and August and initiate growth of reproductive shoots which ultimately grow into stalks (Evans and Black 1993; Takahashi and Huntly 2010). Hypothesis 2 - Fine roots of sagebrush carry the isotopic signature of recently assimilated carbon.

We expected to see a reduction in $\delta^{13} C$ of leaves in irrigated plots compared to controls. A lack of significant effect of treatment as well as across time for changes in $\delta^{13} C$ may be linked 
to low sample size and large variance. Isotope ratio of leaves and roots were used as metrics to assess the impacts of precipitation on the total amount of carbon assimilated across time (Farquhar et al., 1988). Sagebrush leaves acted as carbon sinks following the August pulse, but we found no such evidence in fine roots (Table 3). Low nutrient content in cold desert ecosystems results in low root maintenance respiration, which in turn leads to increased lifespan of the shrub roots (Dobrowolski et al., 1990 ; Ryser, 1996), making them resilient to drought but potentially less responsive to precipitation pulses.

New carbon assimilates may have led to increased maintenance cost of existing roots (Ivans et al., 2003; Snyder et al., 2004) and investment of carbon in deeper soil (Caldwell 1985; Caldwell and Richards, 1986). Carbone and Trumbore (2007) attributed high winter precipitation and access to water table to modulate the low belowground carbon investment by sagebrush in the early and late growing season in Owens Valley, California.

Hypothesis 3 - Different environmental drivers regulate soil $\left(R_{\mathrm{s}}\right)$ and heterotrophic respiration $\left(R_{\mathrm{h}}\right)$ during different times across the summer season in response to a large precipitation pulse.

The high flux rates of $R_{\mathrm{S}}$ and $R_{\mathrm{h}}$ on day 1 (Figure 5) highlight the importance of carbon loss following irrigation treatment in arid and semi-arid ecosystems (Bachman et al., 2010). We hypothesize the primary abiotic factor which may have modulated respiration is displacement of carbon dioxide from soil pore spaces (Huxman et al., 2004b). Biotic factors that may have influenced carbon loss include initiation of microbial activity (Garcia-Pichel and Belnap, 1996), microbial oxidation of labile soil organic matter (Appel 1998), release of labile organic matter on account of osmotic shock (Kieft et al., 1987) and oxidation of cytoplasmic solutes (Fierer and Schimel, 2003). Decomposition of roots in the trenched plots may also have attributed to the high flux values (Lavigne et al., 2004). Glyphosate application could potentially bias the 
heterotrophic respiration estimate. While glyphosate has been known to be harmless to microbes, excess application has been known to enhance carbon flux from microbes (Ratcliff et al., 2006). Increase in carbon flux values on day 7 can be attributed to natural rainfall event before day 7 (based on field observation). Since we did not find any change in $\Psi_{\mathrm{pd}}$ or $\theta_{\mathrm{s}}$, it appears that the precipitation only activated the microbes.

The contribution of carbon assimilates to $R_{\mathrm{S}}$ or $R_{\mathrm{h}}$ however remains unclear as we found no significant effect of treatment in either $\delta^{13} C_{\text {root }}$ (Figures $4 \mathrm{C}-\mathrm{D}$, Table 2) or $\delta^{13} C_{\text {trench }}$ (Figures 4E-F, Table 2 ). $R_{\mathrm{h}}$ was however higher than $R_{\mathrm{s}}$, which we attribute to lack of canopy interception and higher plant water uptake in the trench plots. $R_{\mathrm{S}}$ increased significantly following the August pulse in a similar way to $A_{\mathrm{n}}$. Most of this response can be attributed to increase in $R_{\mathrm{h}}$, suggesting that root respiration did not strongly respond to irrigation within a span of 7 days. Lack of any significant relationship between $\Psi_{\mathrm{pd}}$ and $R_{\mathrm{s}}$ possibly implies different time lags in the response of root activity and water uptake to irrigation. We speculate that roots either had longer lags than observed or required greater background precipitation to respond to experimental pulses.

The different drivers of soil and heterotrophic respiration (Table 4) in July and August reflect upon the different kinetics of carbon dioxide production in roots and microbes across season. If seasonal controls of respiration are not taken into account in modeling respiration, we run the risk of overestimating the influence of environmental controls on respiration (Lavigne et al., 2004). The positive relationship between moisture and soil respiration in July confirms prior work indicating seasonal differences in the response of respiration to moisture availability (Bachman et al., 2010). Covariation of soil moisture and temperature (Davidson et al., 1998) probably accounted for the negative relationship with moisture but positive association with the multiplicative effects of moisture and temperature. 
Limitations and Implications

Vertical and lateral root distribution are important aspects that influence the rate of carbon uptake. Root distribution studies across a similar site in Wyoming have found that the majority of the roots are in the top $50 \mathrm{~cm}$ or even at more shallow depths (Cleary et al., 2010). While sagebrush roots across our study site do extend up to $1 \mathrm{~m}$ consistent with other studies (Richards and Caldwell, 1987), they do not contribute much of the total root mass by percentage (Cleary et al., 2010). The extent of soil moisture recharge at the deeper soil layers as well as that of hydraulic redistribution in inducing carbon gain and the overall plant water status remains unexplored. Empirical analyses from root sensors on a different sub-species of sagebrush in Wyoming demonstrated strong signals of hydraulic redistribution (Naithani et al., 2012). The influence of winter precipitation in modulating vegetation response to large rain event should also be investigated. Our inability to link precipitation to fine root turnover rate suggests photosynthetic carbon may either have been allocated belowground or been utilized for maintenance. With climate change predicting increase in intensity and frequency of large precipitation events, the fate of increase carbon uptake on the overall biomass accumulation represents an important knowledge gap. We did not extend our analysis beyond 7 days because most of our physiological metrics reached pre-irrigation values by day 7 . The high degree of variation as well as sample space may have contributed to the lack of statistical significance in some of our analysis. However, we believe this sample size coupled with our random sampling procedure was representative of the population. Moreover, each measurement point was the average of six to nine measurement points. More importantly, measurements had to be conducted within a specific time-frame. For example, photosynthesis and respiration measurements had to be conducted within $9 \mathrm{am}-12$ noon in order to capture the peak responses. A larger sample size 
would have pushed the measurement time frame beyond $1 \mathrm{pm}$. This would have incorporated time-dependent errors into our analyses. Moreover, in environmental studies, $\mathrm{p}$-value alone should not serve as evidence against the pattern in our data or our underlying research objectives (Berger and Wolpert, 1988, Royall 1997, Lele 2004; Valpine et al., 2014). As observed by many ecologists, lack of statistical significance should not be dismissed as biologically/ecologically insignificant (Jones \& Matloff, 1986; Gerrodette 2011). Compared to statistical significance, the evidence of the effect of large precipitation pulses on the carbon metabolism of shrubs is more informative. The parameters of biological interest derived from our research should be analyzed from the perspective of empirical reproducibility in future research work.

\subsection{Conclusions}

This short-term ecophysiological study highlights the conservative nature of sagebrush vegetation in response to large rain events with potential application to other shrubs in cold desert ecosystems. Different aspects of plant carbon budgets (assimilation, transport and respiration) display similarities in their response to increased resource availability. The increase in aboveground plant process as well as soil and heterotrophic respiration was ephemeral. While hydraulic limitation seems to be a critical factor in influencing the response of photosynthesis of sagebrush to pulse inputs, the role of non-stomatal factors in modulating the response of carbon assimilation could not be definitely established. Fine roots in the upper $30-\mathrm{cm}$ of soil do not appear to be the sink for recently assimilated carbon, suggesting carbon could either been used up for maintenance or been transferred to the roots at depths greater than $30 \mathrm{~cm}$. High contribution of heterotrophic respiration to total soil respiration demonstrates the importance of separate analysis of microbial respiration. The different drivers of soil and heterotrophic 
respiration in July and August accentuate the importance of including seasonal variation for

accurate estimation of respiration flux.

Acknowledgements :This study was supported by funding provided by DOE-NICCR, The Abrahams and Woldenberg Field Scholarship (Department of Geography, University at Buffalo) ,Mark Diamond Research Fund (University at Buffalo), USDA-CSREES grant \# 2003-3510113652, Department of Energy (DOE) Office of Biological and Environmental Research, National Institute for Climatic Change Research (NICCR) Midwestern region sub-agreement $050516 Z 20$ (University at Buffalo), McIntire-Stennis (University of Wyoming), the Wyoming Water Development Commission and the US Geological Survey. A very special note of thanks to Nathan Luke, Courtney Ellis and Claire Hudson for all their help during data collection and to Dr Yolima Carrillo and Dr Sikha Sharma at the Stable Isotope facility at University of Wyoming for their help during the isotope analysis . 


\subsection{References}

Anderson, J.E., Inouye, R.S., 2001. Landscape-scale changes in plant species abundance and biodiversity of a sagebrush steppe over 45 years. Ecological Monographs 71, 531-556.

Appel, T., 1998. Non-biomass soil organic $\mathrm{N}$ - the substrate for $\mathrm{N}$ mineralization flushes following soil drying-rewetting and for organic $\mathrm{N}$ rendered $\mathrm{CaCl}$-extractable upon soil drying. Soil Biology \& Biochemistry 30, 1445-1456.

Bachman, S., Heisler-White, J.L., Pendall, E., Williams, D.G., Morgan, J.A., Newcomb, J., 2010. Elevated carbon dioxide alters impacts of precipitation pulses on ecosystem photosynthesis and respiration in a semi-arid grassland. Oecologia 162, 791-802.

Barbosa, R.I., Silva dos Santos, J.R., da Cunha, M.S., Pimentel, T.P., Fearnside, P.M., 2012. Root biomass, root: shoot ratio and belowground carbon stocks in the open savannahs of Roraima, Brazilian Amazonia. Australian Journal of Botany 60, 405-416.

BassiriRad, H., Tremmel, D.C., Virginia, R.A., Reynolds, J.F., de Soyza, A.G., Brunell, M.H., 1999. Short-term patterns in water and nitrogen acquisition by two desert shrubs following a simulated summer rain. Plant Ecology 145, 27-36.

Berger, J. O., and Wolpert, R.L., 1988. The likelihood principle: a review, generalizations, and statistical implications. Second edition. IMS lecture notes. Monograph series, volume 6. Institute of Mathematical Statistics, Hayward, California, USA

Bierhuizen, J.F., Slatyer, R.O., 1965. Effect of atmospheric concentration of water vapour and $\mathrm{CO} 2$ in determining transpiration- photosynthesis relationships of cotton leaves. Agricultural Meteorology 2, 259-270

Bond-Lamberty, B., Wang, C.K., Gower, S.T., 2004. A global relationship between the heterotrophic and autotrophic components of soil respiration? Global Change Biology 10, 17561766.

Caldwell, M.M., 1985. Cold deserts. In:Chabot BF, Mooney HA (eds) Physiological ecology of North American plant communities. Chapman and Hall, New York, pp 198 - 212

Caldwell, M.M, Richards, J.H., 1986. Competing root systems: morphology and models of absorption. In:Givnish TJ (ed) On the economy of plant form and function. Cambridge University Press, Cambridge, pp 251-273

Carbone, M.S., Trumbore, S.E., 2007. Contribution of new photosynthetic assimilates to respiration by perennial grasses and shrubs: residence times and allocation patterns. New Phytologist 176, 124-135. 
Chen, S., Lin, G., Huang, J., Jenerette, G.D., 2009. Dependence of carbon sequestration on the differential responses of ecosystem photosynthesis and respiration to rain pulses in a semiarid steppe. Global Change Biology 15, 2450-2461.

Cleary, M.B., Pendall, E., Ewers, B.E., 2010. Aboveground and Belowground Carbon Pools After Fire in Mountain Big Sagebrush Steppe. Rangeland Ecology \& Management 63, 187-196.

Comstock, J., Ehleringer, J., 1986. Canopy dynamics and carbon gain in response to soil-water availability in encelia-frutescens gray, a drought-deciduous shrub. Oecologia 68, 271-278.

Craine, J.M., Wedin, D.A., Chapin, F.S., III., 1998. Predominance of ecophysiological controls on soil CO2 flux in a Minnesota grassland. Plant and Soil 207, 77-86.

Cui, M.Y., Caldwell, M.M., 1997. A large ephemeral release of nitrogen upon wetting of dry soil and corresponding root responses in the field. Plant and Soil 191, 291-299.

Davidson, E.A., Belk, E., Boone, R.D., 1998. Soil water content and temperature as independent or confounded factors controlling soil respiration in a temperate mixed hardwood forest. Global Change Biology 4, 217-227.

Davis, S.D., Mooney, H.A., 1986. Water-use patterns of 4 cooccurring chaparral shrubs. Oecologia 70, 172-177.

de Graaff, M.-A., Throop, H.L., Verburg, P.S.J., Arnone, J.A., III, Campos, X., 2014. A Synthesis of Climate and Vegetation Cover Effects on Biogeochemical Cycling in Shrub-Dominated Drylands. Ecosystems 17, 931-945.

de Miguel, M., Sánchez-Gómez, D., Cervera, M.T., Aranda, I., 2011. Functional and genetic characterization of gas exchange and intrinsic water use efficiency in a full-sib family of Pinus pinaster Ait. In response to drought. Tree Physiology 32, 94-103

dePury, D.G.G., Farquhar, G.D., 1997. Simple scaling of photosynthesis from leaves to canopies without the errors of big-leaf models. Plant Cell and Environment 20, 537-557.

de Souza, C.R., Maoroco, J.P., dos Santos, T.P., Rodrigues, M.L., Lopes, C.M., Pereira, J.S., Chaves, M.M., 2005. Impact of deficit irrigation on water use efficiency and carbon isotope composition $\left(\delta^{13} \mathrm{C}\right)$ field-grown grapevines under Mediterranean climate. Journal of Experimental Botany 56(48), 2163-2172

Dobrowolski J.P, Caldwell M.M, Richards J.H., 1990. Basin hydrology and plant root systems. In: Osmond CB, Pitelka LF, Hidy GM, eds. Plant biology of the basin and range. Berlin, Germany: Springer-Verlag, 243-292

Dougherty, R.L., Lauenroth, W.K., Singh, J.S., 1996. Response of a grassland cactus to frequency and size of rainfall events in a North American shortgrass steppe. Journal of Ecology 84, 177-183. 
Ehleringer, J., Pearcy, R.W., 1983. Variation in quantum yield for co2 uptake among c-3 and c-4 plants. Plant Physiology 73, 555-559.

Ehleringer, J.R., Dawson, T.E., 1992. Water-uptake by plants - perspectives from stable isotope composition. Plant Cell and Environment 15, 1073-1082.

Ehleringer, J.R., Phillips, S.L., Schuster, W.S.F., Sandquist, D.R., 1991. Differential utilization of summer rains by desert plants. Oecologia 88, 430-434.

Ehret, D.L., Boyer, J.S., 1979. Potassium-loss from stomatal guard-cells at low water potentials. Journal of Experimental Botany 30, 225-234.

Evans, R.D., Black, R.A., 1993. Growth, photosynthesis, and resource investment for vegetative and reproductive modules of artemisia-tridentata. Ecology 74, 1516-1528.

Ewers, B.E., Pendall, E., 2008. Spatial patterns in leaf area and plant functional type cover across chronosequences of sagebrush ecosystems. Plant Ecology 194, 67-83.

Farquhar, G.D., Caemmerer, S.V., Berry, J.A., 1980. A biochemical-model of photosynthetic co2 assimilation in leaves of c-3 species. Planta 149, 78-90.

Farquhar, G.D and Caemmerer, S.V 1982. Modeling of photosynthetic responses to environmental conditions. In: O.L. Lange, P.S. Nobel, C.B. Osmond and H. Ziegler, Editors, Encyclopedia of Plant Physiology (New Series), Springer-Verlag, Berlin, pp 549- 587.

Farquhar, G. D., Hubick, K. T., Condon, A. G., Richards, R. A. 1988. Carbon isotope fractionation and plant water-use efficiency. In Stable Isotopes in Ecological Research, ed. P. W. Rundel, J. R. Ehleringer, K. A. Nagy, pp. 21-40. New York: Springer-Verlag

Fierer, N., Schimel, J.P., 2003. A proposed mechanism for the pulse in carbon dioxide production commonly observed following the rapid rewetting of a dry soil. Soil Science Society of America Journal 67, 798-805.

Flanagan, L.B., Ehleringer, J.R., Marshall, J.D., 1992. Differential uptake of summer precipitation among cooccurring trees and shrubs in a pinyon-juniper woodland. Plant Cell and Environment $15,831-836$.

Flexas, J., Medrano, H., 2002. Drought-inhibition of photosynthesis in C-3 plants: Stomatal and non-stomatal limitations revisited. Annals of Botany 89, 183-189.

Flexas, J., Bota, J., Galmes, J., Medrano, H., Ribas-Carbo, M., 2006. Keeping a positive carbon balance under adverse conditions: responses of photosynthesis and respiration to water stress. Physiologia Plantarum 127, 343-352. 
Galmes J., Conesa M.A., Ochogavia J.M., Perdomo J.A., Francis D.M., Ribas-Carbo M., Save R., Flexas J., Medrano H. \& Cifre J. 2011. Physiological and morphological adaptations in relation to water use efficiency in Mediterranean accessions of Solanum lycopersicum. Plant, Cell \& Environment 34, 245-260.

GarciaPichel, F., Belnap, J., 1996. Microenvironments and microscale productivity of cyanobacterial desert crusts. Journal of Phycology 32, 774-782.

Garten C.T., Taylor, G.E., 1992. Foliar d13C within a temperate deciduous forest: spatial, temporal, and species sources of variation. Oecologia 90, 1-7.

Gebauer, R.L.E., Ehleringer, J.R., 2000. Water and nitrogen uptake patterns following moisture pulses in a cold desert community. Ecology 81, 1415-1424.

Gerrodette, T., 2011. Inference without significance: measuring support for hypotheses rather than rejecting them. Marine Ecology 32, 404-418

Girden E.R., 1992. ANOVA: Repeated Measures (Sage university paper series on qualitative applications in the social sciences, 84), Newbury Park, CA: Sage.

Golluscio, R.A., Sala, O.E., Lauenroth, W.K., 1998. Differential use of large summer rainfall events by shrubs and grasses: a manipulative experiment in the Patagonian steppe. Oecologia 115, $17-25$.

Grassi, G., Magnani, F., 2005. Stomatal, mesophyll conductance and biochemical limitations to photosynthesis as affected by drought and leaf ontogeny in ash and oak trees. Plant Cell and Environment 28, 834-849.

Guehl, J.-M., Fort, C., Ferhi.A., 1995. Differential response of leaf conductance, carbon isotope discrimination and water-use efficiency to nitrogen deficiency in maritime pine and pedunculate oak plants. New Phytol. 131, 149-157.

Hanson, P.J., Edwards, N.T., Garten, C.T., Andrews, J.A., 2000. Separating root and soil microbial contributions to soil respiration: A review of methods and observations. Biogeochemistry 48, 115146.

Henson, I.E., Mahalakshmi, V., Alagarswamy, G., Bidinger, F.R., 1984. Leaf abscisic-acid content and recovery from water-stress in pearl-millet (pennisetum-americanum [1] leeke). Journal of Experimental Botany 35, 99-109.

Hogberg, P., Nordgren, A., Buchmann, N., Taylor, A.F.S., Ekblad, A., Hogberg, M.N., Nyberg, G., Ottosson-Lofvenius, M., Read, D.J., 2001. Large-scale forest girdling shows that current photosynthesis drives soil respiration. Nature 411, 789-792. 
Holthausen, R.S., Caldwell, M.M., 1980. Seasonal dynamics of root-system respiration in atriplexconfertifolia. Plant and Soil 55, 307-317.

Huxman, T.E., Cable, J.M., Ignace, D.D., Eilts, J.A., English, N.B., Weltzin, J., Williams, D.G., 2004a. Response of net ecosystem gas exchange to a simulated precipitation pulse in a semi-arid grassland: the role of native versus non-native grasses and soil texture. Oecologia 141, 295-305.

Huxman, T.E., Snyder, K.A., Tissue, D., Leffler, A.J., Ogle, K., Pockman, W.T., Sandquist, D.R., Potts, D.L., Schwinning, S., 2004b. Precipitation pulses and carbon fluxes in semiarid and arid ecosystems. Oecologia 141, 254-268.

Intergovernmental Panel on Climate Change (IPCC), 2007. IPCC Fourth Assessment Report Climate Change 2007: The Physical Science Basis. Cambridge University Press, Cambridge

Irvine, J., Law, B.E., Kurpius, M.R., 2005. Coupling of canopy gas exchange with root and rhizosphere respiration in a semi-arid forest. Biogeochemistry 73, 271-282.

Ivans, C.Y., Leffler, A.J., Spaulding, U., Stark, J.M., Ryel, R.J., Caldwell, M.M., 2003. Root responses and nitrogen acquisition by Artemisia tridentata and Agropyron desertorum following small summer rainfall events. Oecologia 134, 317-324.

Jentsch, A., Kreyling, J., Beierkuhnlein, C., 2007. A new generation of climate-change experiments: events, not trends. Frontiers in Ecology and the Environment 5, 365-374.

Johnson, D., Leake, J.R., Read, D.J., 2002. Transfer of recent photosynthate into mycorrhizal mycelium of an upland grassland: short-term respiratory losses and accumulation of C-14. Soil Biology \& Biochemistry 34, 1521-1524.

Jones, D., Matloff, N., 1986. Statistical Hypothesis Testing in Biology: A Contradiction in Terms. Journal of Economic Entomology, 79(5), 1156-1160.

Katul, G., Leuning, R., Oren, R., 2003. Relationship between plant hydraulic and biochemical properties derived from a steady-state coupled water and carbon transport model. Plant Cell and Environment 26, 339-350.

Kieft, T.L., Soroker, E., Firestone, M.K., 1987. Microbial biomass response to a rapid increase in water potential when dry soil is wetted. Soil Biology \& Biochemistry 19, 119-126.

Kolb, K.J., Sperry, J.S., 1999. Transport constraints on water use by the Great Basin shrub, Artemisia tridentata. Plant Cell and Environment 22, 925-935.

Kwon, H., Pendall, E., Ewers, B.E., Cleary, M., Naithani, K., 2008. Spring drought regulates summer net ecosystem $\mathrm{CO} 2$ exchange in a sagebrush-steppe ecosystem. Agricultural and Forest Meteorology 148(3), 381-391. 
Lauenroth, W.K., Sala, O.E., Milchunas, D.G., Lathrop, R.W., 1987. Root dynamics of Bouteloua gracilis during short-term recovery from drought. Functional Ecology 1, 117-124.

Lauteri., M, Scartazza, A., Guido, M.C., Brugnoli, E., 1997 Genetic variation in photosynthetic capacity, carbon isotope discrimination and mesophyll conductance in provenances of Castanea sativa adapted to different environments. Funct Ecol 11, 675-683

Lavigne, M.B., Foster, R.J., Goodine, G., 2004. Seasonal and annual changes in soil respiration in relation to soil temperature, water potential and trenching. Tree Physiology 24, 415-424.

Lele, S.R., 2004. Evidence functions and the optimality of the law of likelihood. Pages 191-216 in M. L. Taper and S. R. Lele, editors. The nature of scientific evidence. University of Chicago Press, Chicago, Illinois, USA

Liu, Q., Edwards, N.T., Post, W.M., Gu, L., Ledford, J., Lenhart, S., 2006. Temperatureindependent diel variation in soil respiration observed from a temperate deciduous forest. Global Change Biology 12, 2136-2145.

Loik, M.E., 2007. Sensitivity of water relations and photosynthesis to summer precipitation pulses for Artemisia tridentata and Purshia tridentata. Plant Ecology 191, 95-108.

Loik, M.E., Breshears, D.D., Lauenroth, W.K., Belnap, J., 2004. A multi-scale perspective of water pulses in dryland ecosystems: climatology and ecohydrology of the western USA. Oecologia 141, 269-281.

Loranty, M.M., Mackay, D.S., Ewers, B.E., Traver, E., Kruger, E.L., 2010, Competition for light between individual trees lowers reference canopy stomatal conductance: Results from a model. Journal of Geophysical Research-Biogeosciences 115.

Lu,Q., Lu, C., 2004. Photosynthetic pigment composition and photosystem II photochemistry of wheat ears.Plant Physiol Biochem, 42(5), 395-402.

Mackay, D.S., Ahl, D.E., Ewers, B.E., Samanta, S., Gower, S.T., Burrows, S.N., 2003. Physiological tradeoffs in the parameterization of a model of canopy transpiration. Advances in Water Resources 26, 179-194.

Maestre, F.T., Valladares, F., Reynolds, J.F., 2005. Is the change of plant-plant interactions with abiotic stress predictable? A meta-analysis of field results in arid environments. Journal of Ecology $93,748-757$.

Maxwell, K., Johnson, G.N., 2000. Chlorophyll fluorescence - a practical guide. Journal of Experimental Botany 51, 659-668.

Medrano, H., Tomás, M., Martorell, S., Flexas, J., Hernández, E., Rosselló, J., Pou, A., Escalona, J., Bota, J., 2015. From leaf to whole-plant water use efficiency (WUE) 
in complex canopies: Limitations of leaf WUE as a selection target. The Crop Journal 3, 220-228

Mitra, B., Mackay, D.S., Pendall, E., Ewers, B.E., Cleary, M.B. 2014, Does vegetation structure regulate the spatial structure of soil respiration within a sagebrush steppe ecosystem? Journal of Arid Environments 103, 1-10.

Miyashita, K.; Tanakamaru, S.; Maitani, T.; Kimura, K., 2005. Recovery responses of photosynthesis, transpiration, and stomatal conductance in kidney bean following drought stress. Environmental and Experimental Botany 53, 205-214.

Naithani, K., 2009. Spatial and Temporal Controls on Population and Flux Processes in Steppe Ecosystems, Ph.D Dissertation, Department of Botany, Program in Ecology, University of Wyoming.

Naithani, K.J., Ewers, B.E., Pendall, E., 2012. Sap flux-scaled transpiration and stomatal conductance response to soil and atmospheric drought in a semi-arid sagebrush ecosystem. Journal of Hydrology 464, 176-185.

Norby, R.J., Jackson, R.B., 2000. Root dynamics and global change: seeking an ecosystem perspective. New Phytologist 147, 3-12.

Ogle, K., Reynolds, J.F., 2004. Plant responses to precipitation in desert ecosystems: integrating functional types, pulses, thresholds, and delays. Oecologia 141, 282-294.

Pockman, W.T., Small, E.E., 2010. The Influence of Spatial Patterns of Soil Moisture on the Grass and Shrub Responses to a Summer Rainstorm in a Chihuahuan Desert Ecotone. Ecosystems 13, 511-525.

Potts, D.L., Huxman, T.E., Enquist, B.J., Weltzin, J.F., Williams, D.G., 2006a. Resilience and resistance of ecosystem functional response to a precipitation pulse in a semi-arid grassland. Journal of Ecology 94, 23-30.

Potts, D.L., Huxman, T.E., Scott, R.L., Williams, D.G., Goodrich, D.C., 2006b. The sensitivity of ecosystem carbon exchange to seasonal precipitation and woody plant encroachment. Oecologia $150,453-463$.

Ratcliff, A.W., Busse, M.D., Shestak, C.J., 2006. Changes in microbial community structure following herbicide (glyphosate) additions to forest soils. Applied Soil Ecology 34, 114-124.

Resco, V., Ignace, D.D., Sun, W., Huxman, T.E., Weltzin, J.F., Williams, D.G., 2008. Chlorophyll fluorescence, predawn water potential and photosynthesis in precipitation pulse-driven ecosystems - implications for ecological studies. Functional Ecology 22, 479-483.

Richards, J.H., Caldwell, M.M., 1987. Hydraulic lift - substantial nocturnal water transport between soil layers by artemisia-tridentata roots. Oecologia 73, 486-489. 
Royall, R.M., 1997. Statistical evidence: a likelihood paradigm. Chapman and Hall, New York, New York, USA

Ryser, P., 1996. The importance of tissue density for growth and life span of leaves and roots: A comparison of five ecologically contrasting grasses. Functional Ecology 10, 717-723.

Samanta, S., Mackay, D.S., Clayton, M.K., Kruger, E.L., Ewers, B.E., 2007. Bayesian analysis for uncertainty estimation of a canopy transpiration model. Water Resources Research 43.

Schenk, H.J., Jackson, R.B., 2002. Rooting depths, lateral root spreads and below-ground/aboveground allometries of plants in water-limited ecosystems. Journal of Ecology 90, 480-494.

Schwinning, S., Davis, K., Richardson, L., Ehleringer, J.R., 2002. Deuterium enriched irrigation indicates different forms of rain use in shrub/grass species of the Colorado Plateau. Oecologia 130, 345-355.

Schwinning, S., Sala, O.E., 2004. Hierarchy of responses to resource pulses in and and semi-arid ecosystems. Oecologia 141, 211-220.

Schwinning, S., Starr, B.I., Ehleringer, J.R., 2003. Dominant cold desert plants do not partition warm season precipitation by event size. Oecologia 136, 252-260.

Schwinning, S., Starr, B.I., Ehleringer, J.R., 2005. Summer and winter drought in a cold desert ecosystem (Colorado Plateau) part II: effects on plant carbon assimilation and growth. Journal of Arid Environments 61, 61-78.

Snyder K.A., Donovan L.A., James, J.J., Tiller, R.L. and Richards, J.H., 2004. Extensive summer water pulses do not necessarily lead to canopy growth of Great Basin and northern Mojave Desert shrubs. Oecologia. 141(2), 325-334.

Sperry, J.S., Hacke, U.G., 2002. Desert shrub water relations with respect to soil characteristics and plant functional type. Functional Ecology 16, 367-378.

Takahashi, M., Huntly, N., 2010. Herbivorous insects reduce growth and reproduction of big sagebrush (Artemisia tridentata). Arthropod-Plant Interactions 4, 257-266.

Valladares, E., Pearcy, R.W., 1997. Interactions between water stress, sun-shade acclimation, heat tolerance and photoinhibition in the schlerophyll Heteromeles arbutifolia. Plant Cell Environment, 20, 25-36.

Valpine, P.D., 2014. The common sense of P values. Ecology 95(3), 617-621

Xie J., Zha, T., Jia, X., Qian, D., Wu, B., Zhang, Y., Bourque, C.P.A., Chen, J., Sun, G and Peltola, H., 2015. Irregular precipitation events in control of seasonal variations in CO2 exchange in a cold desert-shrub ecosystem in northwest China. Journal of Arid Environment 120, 33 -41 
Yan, S.G., Wan, C.G., Sosebee, R.E., Wester, D.B., Fish, E.B., Zartman, R.E., 2000. Responses of photosynthesis and water relations to rainfall in the desert shrub creosote bush (Larrea tridentata) as influenced by municipal biosolids. Journal of Arid Environments 46, 397-412.

Zegada-Lizarazu, W., Berliner, P.R., 2011. Inter-row Mulch Increase the Water Use Efficiency of Furrow-Irrigated Maize in an Arid Environment. Journal of Agronomy and Crop Science 197, 237-248.

Zhang, J., Marshall, J.D., Jaquish, B.C., 1993. Genetic differentiation in carbon isotope discrimination and gas exchange in Pseudotsuga menziesii. Oecologia 93, 80-87. 


\section{List of Tables}

Table 1: Time schedule of the irrigation experiment in the Sagebrush and Trench plot in July and August, 2009 at Saratoga, Wyoming

Table 2: Summary of the analysis of Repeated ANOVA for July and August. The measured variables included predawn water potential $\left(\Psi_{\mathrm{pd}}\right)$, stomatal conductance $\left(g_{\mathrm{s}}\right)$, photosynthesis $\left(A_{\mathrm{n}}\right)$, quantum yield ( $\left.\Phi_{\mathrm{PSII}}\right)$, potential quantum efficiency for light adapted leaves $\left(F_{\mathrm{v}}{ }^{\prime} / F_{\mathrm{m}}{ }^{\prime}\right)$, isotope measurement of leaf respired $\mathrm{CO}_{2}\left(\delta^{13} C_{\text {leaf }}\right)$, isotope measurement of root-respired $\mathrm{CO}_{2}$ ( $\delta^{13} C_{\text {root }}$, isotope measurement of root-respired $\mathrm{CO}_{2}$ from trench plots $\left(\delta^{13} C_{\text {trench }}\right)$, soil respiration $\left(R_{\mathrm{S}}\right)$, heterotrophic respiration $\left(R_{\mathrm{h}}\right)$, soil moisture in the respiration plots $\left(\theta_{\mathrm{s}}\right)$, soil moisture in the trench plots $\left(\theta_{\mathrm{h}}\right)$, soil temperature of the respiration plots $\left(T_{\mathrm{s}}\right)$, and soil temperature of the trench plots $\left(T_{\mathrm{h}}\right)$. Treat refers to Treatment and $*$ signifies statistical significance at 0.05 level.

Table 3: Correlation analysis between $\Delta A_{n}$ and $\Delta \delta^{13} C_{1}$ (and $\Delta \delta^{13} C_{\mathrm{r}}$ ) in both July and August for different lag hours with respect to $15: 00 \mathrm{hrs} . \Delta A_{n}$ is the difference in carbon accumulated between irrigated and non-irrigated plots. $\Delta \delta^{13} C_{1}$ is the difference in isotope value of leaves between irrigated and non-irrigated plots. $\Delta \delta^{13} C_{\mathrm{r}}$ is the difference in isotope value of roots between irrigated and non-irrigated plots. $\delta^{13} \mathrm{C}$ values were reported in \%o with respect to Vienna Pee Dee Belemnite (V-PDB). $A_{n}$ values were in $\mu \mathrm{mol} \mathrm{m} \mathrm{m}^{-2} \mathrm{~s}^{-1}$.

Table 4: Summary output of the regression parameters and statistics describing the relationship between total soil respiration $\left(R_{\mathrm{S}}\right)\left(\&\right.$ heterotrophic respiration $\left.\left(R_{\mathrm{h}}\right)\right)$ and the environmental drivers, 
including soil moisture $\left(\theta_{\mathrm{s}}\right)\left(\&\right.$ soil moisture $\left(\theta_{\mathrm{h}}\right)$ in trench plots) and soil temperature $\left(T_{\mathrm{s}}\right)(\&$ soil temperature $\left(T_{\mathrm{h}}\right)$ in trench plots $)$. 


\section{List of Figures}

Figure 1: Comparison of the dynamics of the response of soil moisture (Figures $1 \mathrm{~A} \& 1 \mathrm{~B}, \theta_{\mathrm{s}}$ ), soil temperature (Figures $1 \mathrm{C} \& 1 \mathrm{D}, T_{\mathrm{S}}$ ) content in the soil respiration plots as well as soil moisture (Figures $1 \mathrm{E} \& 1 \mathrm{~F}, \theta_{\mathrm{h}}$ ) and soil temperature (Figures $1 \mathrm{G} \& 1 \mathrm{H}, T_{\mathrm{h}}$ ) in the trench plots in July and August. Data are Mean \pm SE for $n=3$ plants for each treatment. * highlights significant difference between irrigated and non-irrigated treatments at $\mathrm{p}<0.05$ level.

Figure 2: Comparison of the dynamics of the response of photosynthesis (Figures $2 \mathrm{~A} \& 2 \mathrm{~B}, A_{\mathrm{n}}$ ), predawn water potential (Figures 2C \& 2D, $\Psi_{\mathrm{pd}}$ ), stomatal conductance (Figures $2 \mathrm{E} \& 2 \mathrm{~F}, g_{\mathrm{s}}$ ) and potential quantum efficiency of light adapted leaves (Figures $2 \mathrm{G} \& 2 \mathrm{H}, F_{\mathrm{v}}{ }^{\prime} / F_{\mathrm{m}}{ }^{\prime}$ ) of the irrigated and non-irrigated plot in July and August. Data are Mean \pm SE for $n=3$ plants for each treatment.

* highlights significant difference between irrigated and non-irrigated treatments at $\mathrm{p}<0.05$ level. Average intrinsic water use efficiency $\left(W U E_{\mathrm{i}}, \mu \mathrm{mol} \mathrm{CO} \mathrm{CO}_{2}\right.$ per $\left.\mathrm{mol}_{2} \mathrm{O}\right)$ of the irrigated and nonirrigated plot in July and August have been shown in Figures 2E \& 2F.

Figure 3: Correlation analysis between photosynthesis $\left(A_{\mathrm{n}}\right)$ and predawn water potential (Figures $3 \mathrm{~A} \& 3 \mathrm{~B}, \Psi_{\mathrm{pd}}$ ), potential quantum efficiency (Figures $3 \mathrm{C} \& 3 \mathrm{D}, F_{\mathrm{v}}{ }^{\prime} / F_{\mathrm{m}}{ }^{\prime}$ ) and stomatal conductance (Figures 3E \& 3F, $g_{s}$ ) in July and August

Figure 4: Kinetics of the variation in isotope composition $\left(\delta^{13} \mathrm{C}\right)$ of the leaves (Figures 4A \& 4B) and roots (Figures $4 \mathrm{C}-4 \mathrm{~F}$ ) with respect to (w.r.t) corresponding isotope value on day -1 for the 
irrigated and trench plots. $\delta^{13} \mathrm{C}$ values were reported in \%o with respect to Vienna Pee Dee Belemnite (V-PDB)

Figure 5: Kinetics of the response of total soil respiration (Figures $5 \mathrm{~A} \& 5 \mathrm{~B}, R_{\mathrm{S}}$ ) and heterotrophic respiration (Figures $5 \mathrm{C} \& 5 \mathrm{D}, R_{\mathrm{h}}$ ) in July and August. Data are Mean $\pm \mathrm{SE}$ for $\mathrm{n}=3$ plants for each treatment. * highlights significant difference between irrigated and non-irrigated treatments at $\mathrm{p}<0.05$ level.

Figure 6: Relationship between predawn water potential $\left(\Psi_{\mathrm{pd}}\right)$ and total soil respiration $\left(R_{\mathrm{s}}\right)$ for both the treatments in July (Figure 6A) and August (Figure 6B).

Figure Appendix A1: Time series of the A) 30 year (1980 - 2009) average of total precipitation $(\mathrm{mm})$ as well as in total precipitation $(\mathrm{mm})$ in 2009 , B) 30 year $(1980-2009)$ average monthly temperature $\left({ }^{\circ} \mathrm{C}\right)$ as well as in $2009\left({ }^{\circ} \mathrm{C}\right)$ as well as C) Frequency of 30-year average $(1980-2009)$ precipitation bins for July and August. (www.wrcc.dri.edu).

Figure Appendix A2: Time series of the average daily precipitation ( $\mathrm{mm})$ in July and August and the duration of the two experiment period $(-1,1,3,5,7)$. Precipitation data was obtained from Rawlins (< 45 miles from Saratoga and at same elevation) (www.wrcc.dri.edu). 
Table 1:

\begin{tabular}{lllllll}
\hline Day & -1 & 0 & 1 & 3 & 5 & 7 \\
\hline \multicolumn{2}{l}{ Sagebrush Plots } & & & & & \\
\hline 03-05 hrs & & $\Psi_{\mathrm{pd}}$ & $\Psi_{\mathrm{pd}}$ & $\Psi_{\mathrm{pd}}$ & $\Psi_{\mathrm{pd}}$ & $\Psi_{\mathrm{pd}}$ \\
09-12 hrs & $A_{\mathrm{n}} \& R$ & Pulse & $A_{n} \& R$ & $A_{n} \& R$ & $A_{n} \& R$ & $A_{n} \& R$ \\
$13-15 \mathrm{hrs}$ & $\delta^{13} C$ & Treatment & $\delta^{13} C$ & $\delta^{13} C$ & $\delta^{13} C$ & $\delta^{13} C$ \\
\hline Trench Plots & & & & & & \\
\hline 09-12 hrs & $R$ & Pulse & $R$ & $R$ & $R$ & $R$ \\
13-15 hrs & $\delta^{13} C$ & Treatment & $\delta^{13} C$ & $\delta^{13} C$ & $\delta^{13} C$ & $\delta^{13} C$ \\
\hline
\end{tabular}


Table 2:

\begin{tabular}{|c|c|c|c|c|c|c|c|c|c|c|c|}
\hline Factors & $\mathrm{df}$ & $\mathrm{F}$ & Factors & $\mathrm{df}$ & $\mathrm{F}$ & Factors & $\mathrm{df}$ & $\mathrm{F}$ & Factors & df & $\mathrm{F}$ \\
\hline$\Psi_{\mathrm{pd}}$ & & & & & & $g_{\mathrm{s}}$ & & & & & \\
\hline July & & & August & & & July & & & August & & \\
\hline Time & 4,16 & $18.22^{*}$ & Time & 4,16 & $26.49 *$ & Time & $3.08,12.32$ & 1.41 & Time & $2.24,17.91$ & 1.72 \\
\hline Timex & 4,16 & $3.21 *$ & Timex & 4,16 & $15.14^{*}$ & Timex & $3.08,12.32$ & 1.32 & Timex & $2.24,17.91$ & 2.17 \\
\hline Treat. & & & Treat. & & & Treat. & & & Treat. & & \\
\hline Treat. & 1,4 & 1.76 & Treat. & 1,4 & $10.05^{*}$ & Treat. & 1,4 & 4.63 & Treat. & 1,8 & $18.89 *$ \\
\hline$A_{n}$ & & & & & & $F_{\mathrm{v}}{ }^{\prime} / F_{\mathrm{m}}{ }^{\prime}$ & & & & & \\
\hline July & & & August & & & July & & & August & & \\
\hline Time & $3.19,31.92$ & 0.49 & Time & 4,32 & 1.50 & Time & 4,16 & $3.55^{*}$ & Time & $3.51,28.09$ & $6.18 *$ \\
\hline Timex & $3.19,31.92$ & 0.63 & Timex & 4,32 & 2.30 & Timex & 4,16 & $4.09 *$ & Timex & $3.51,28.09$ & $5.42 *$ \\
\hline Treat. & & & Treat. & & & Treat. & & & Treat. & & \\
\hline Treat. & 1,10 & 7.03 & Treat. & 1,8 & $0.02 *$ & Treat. & 1,4 & 2.59 & Treat. & 1,8 & 0.33 \\
\hline$\Phi_{\mathrm{PSII}}$ & & & & & & $\delta^{13} C_{\text {leaf }}$ & & & & & \\
\hline July & & & August & & & July & & & August & & \\
\hline Time & $3.82,15.27$ & $3.34 *$ & Time & 4,32 & $4.35^{*}$ & Time & 4,16 & $7.76^{*}$ & Time & 4,16 & 0.95 \\
\hline Timex & $3.82,15.27$ & $2.86^{* * *}$ & Timex & 4,32 & $3.64 *$ & Timex & 4,16 & 0.76 & Timex & 4,16 & 1.59 \\
\hline Treat. & & & Treat. & & & Treat. & & & Treat. & & \\
\hline Treat. & 1,4 & 3.94 & Treat. & 1,8 & 1.64 & Treat. & 1,4 & 0.18 & Treat. & 1,4 & 1.84 \\
\hline$\delta^{13} C_{\text {root }}$ & & & & & & $\delta^{13} C_{\text {trench }}$ & & & & & \\
\hline July & & & August & & & July & & & August & & \\
\hline Time & 4,16 & 0.41 & Time & 4,16 & 2.01 & Time & 4,16 & 0.45 & Time & 4,16 & 2.42 \\
\hline Timex & 4,16 & 0.1 & Timex & 4,16 & 1.3 & Timex & 4,16 & 0.13 & Timex & 4,16 & 1.23 \\
\hline Treat. & & & Treat. & & & Treat. & & & Treat. & & \\
\hline Treat. & 1,4 & 0.10 & Treat. & 1,4 & 3.36 & Treat. & 1,4 & 0.01 & Treat. & 1,4 & 3.18 \\
\hline$R_{\mathrm{S}}$ & & & & & & $R_{\mathrm{h}}$ & & & & & \\
\hline July & & & August & & & July & & & August & & \\
\hline Time & 4,40 & $9.32 *$ & Time & $2.75,27.51$ & $5.77 *$ & Time & 4,16 & 0.46 & Time & 4,16 & 2.42 \\
\hline Timex & 4,40 & $5.7^{*}$ & Timex & $2.75,27.51$ & $6.88^{*}$ & Timex & 4,16 & 0.13 & Timex & 4,16 & 1.20 \\
\hline Treat. & & & Treat. & & & Treat. & & & Treat. & & \\
\hline Treat. & 1,10 & 2.8 & Treat. & 1,10 & $52.84 *$ & Treat. & 1,4 & 0.01 & Treat. & 1,4 & 3.18 \\
\hline$\theta_{\mathrm{S}}$ & & & & & & $\theta_{\mathrm{h}}$ & & & & & \\
\hline July & & & August & & & July & & & August & & \\
\hline Time & $1.91,19.09$ & $10.31^{*}$ & Time & $2.07,20.67$ & 1.57 & Time & $1.22,12.17$ & $8.96^{*}$ & Time & 4,40 & $4.71 *$ \\
\hline Timex & & $7.56^{*}$ & Timex & $2.07,20.67$ & $5.58 *$ & Timex & $1.22,12.17$ & $3.38 * *$ & Timex & 4,40 & $5.65^{*}$ \\
\hline Treat. & & & Treat. & & & Treat. & & & Treat. & & \\
\hline Treat. & 1,10 & $4.722 * *$ & Treat. & 1,10 & $18.156^{*}$ & Treat. & 1,10 & $17.25 *$ & Treat. & 1,10 & $6.48 *$ \\
\hline$T_{\mathrm{s}}$ & & & & & & $T_{\mathrm{h}}$ & & & & & \\
\hline July & & & August & & & July & & & August & & \\
\hline Time & 4,40 & $13.91^{*}$ & Time & $1.43,14.32$ & $19.54^{*}$ & Time & 4,40 & $33.76^{*}$ & Time & 4,40 & $17.47 *$ \\
\hline Timex & 4,40 & .78 & Timex & $1.43,14.32$ & 2.01 & Timex & 4,40 & $3.67 *$ & Timex & 4,40 & 0.47 \\
\hline Treat. & & & Treat. & & & Treat. & & & Treat. & & \\
\hline Treat. & 1,10 & .78 & Treat. & 1,10 & .25 & Treat. & 1,10 & $8.50^{*}$ & Treat. & 1,10 & 0.3 \\
\hline \multicolumn{12}{|l|}{ WUE $\mathrm{i}$} \\
\hline July & & & August & & & & & & & & \\
\hline Time & 4,16 & 0.96 & Time & 4,16 & 0.123 & & & & & & \\
\hline Timex & 4,16 & 1.63 & Timex & 4,16 & 0.652 & & & & & & \\
\hline Treat. & & & Treat. & & & & & & & & \\
\hline Treat. & 1,4 & 2.28 & Treat. & 1,4 & 0.79 & & & & & & \\
\hline
\end{tabular}


Table 3:

\begin{tabular}{cccccc}
\hline Plant Carbon & Lag Hours & 0 & -3 & -6 & -9 \\
& & & & & \\
\hline Leaves & July & 0.05 & 0.27 & 0.16 & 0.01 \\
& August & $0.92^{*}$ & $0.86^{*}$ & 0.15 & 0.26 \\
\multirow{2}{*}{ Fine Roots } & July & 0.00 & 0.65 & 0.17 & 0.08 \\
& August & 0.27 & 0.37 & 0.08 & 0.02 \\
\hline
\end{tabular}


Table 4:

\begin{tabular}{lllllll}
\hline Time Period & Parameters & Estimate & SE & df & t & Sig \\
\hline$R_{\mathrm{s}}$ & & & & & & \\
\hline July & Intercept & 6.33 & 1.85 & 46.49 & 3.42 & 0.001 \\
& $T_{\mathrm{s}}$ & -0.18 & 0.09 & 46.39 & -1.98 & 0.053 \\
& $\theta_{\mathrm{s}}$ & 0.22 & 0.04 & 39.21 & 5.11 & 0.000 \\
& Intercept & 4.38 & 1.48 & 35.90 & 2.97 & 0.005 \\
& $T_{\mathrm{s}}$ & -0.19 & 0.09 & 36.79 & -2.26 & 0.030 \\
& $\theta_{\mathrm{s}}$ & -0.49 & 0.19 & 41.46 & -2.53 & 0.015 \\
& $\theta_{\mathrm{s}}{ }^{2}$ & 0.013 & 0.01 & 33.97 & 2.18 & 0.036 \\
& $T_{\mathrm{s}} \mathrm{x} \theta_{\mathrm{s}}$ & 0.033 & 0.01 & 45.05 & 4.16 & 0.000 \\
\hline July & & & & & & \\
& Intercept & 4.14 & 0.32 & 44.98 & 12.88 & 0.000 \\
& $\theta_{\mathrm{h}}$ & -0.21 & 0.06 & 41.69 & -3.49 & 0.001 \\
August & $\theta_{\mathrm{h}}{ }^{2}$ & 0.01 & 0.01 & 26.01 & 3.85 & 0.001 \\
& Intercept & 6.49 & 0.89 & 21.94 & 7.27 & 0.000 \\
& Time & -1.12 & 0.24 & 26.80 & -4.73 & 0.000 \\
& $\theta_{\mathrm{h}}$ & -0.32 & 0.14 & 36.96 & -2.23 & 0.032 \\
& $T_{\mathrm{h} . \mathrm{x}} \theta_{\mathrm{h}}$ & 0.02 & 0.01 & 41.88 & 2.24 & 0.031 \\
& & & & & \\
\hline
\end{tabular}




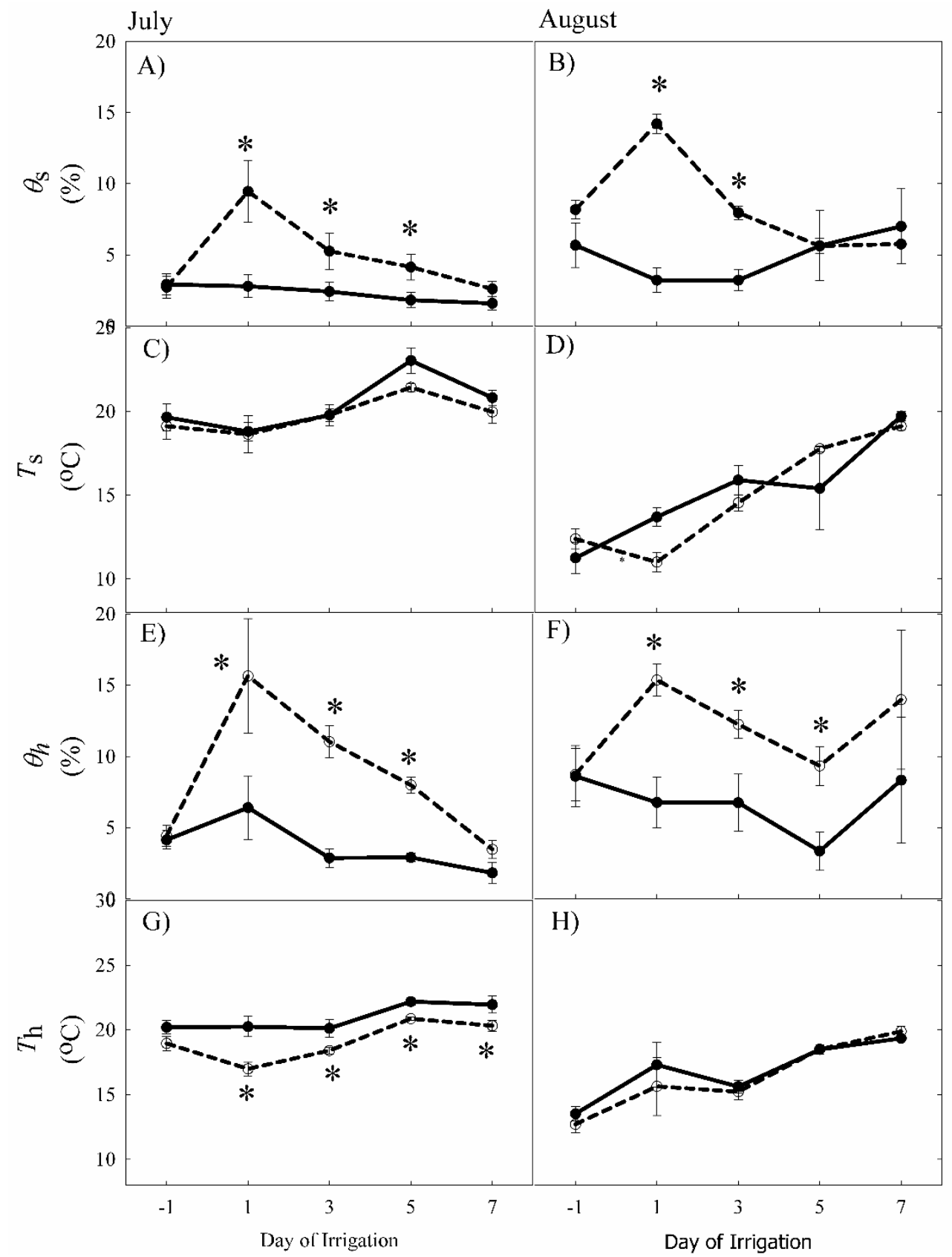

Figure 1: 


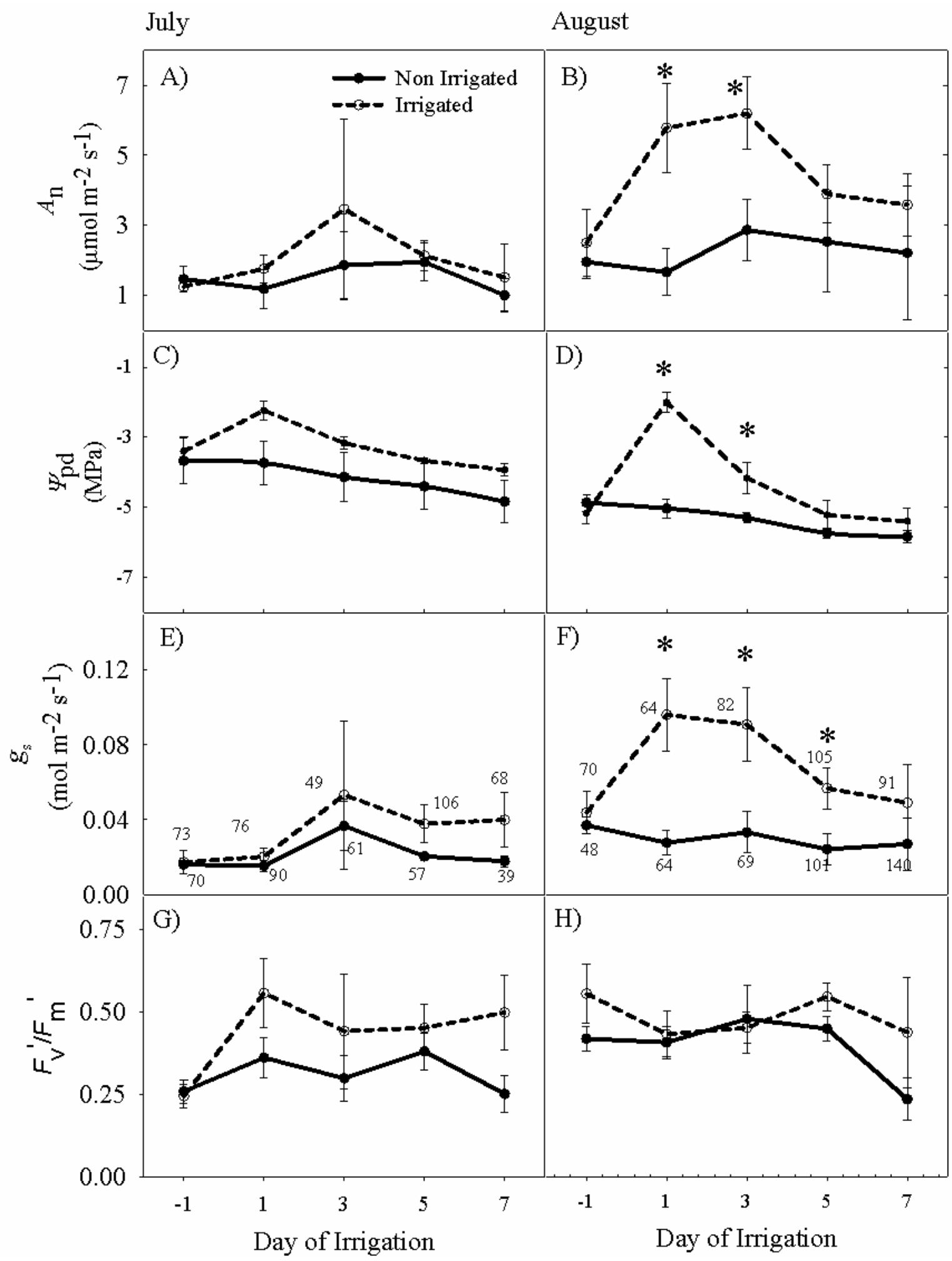

Figure 2: 


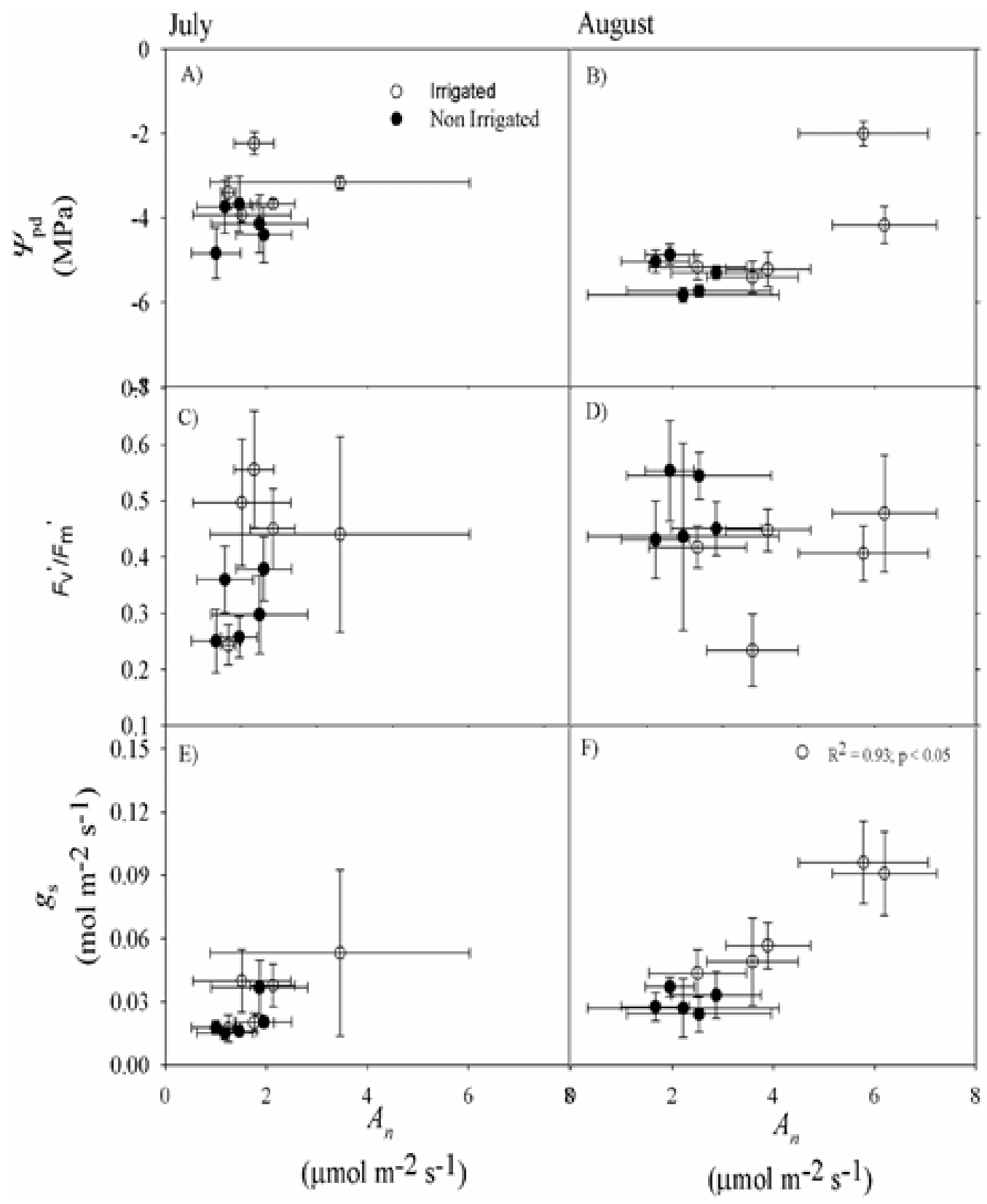

Figure 3: 


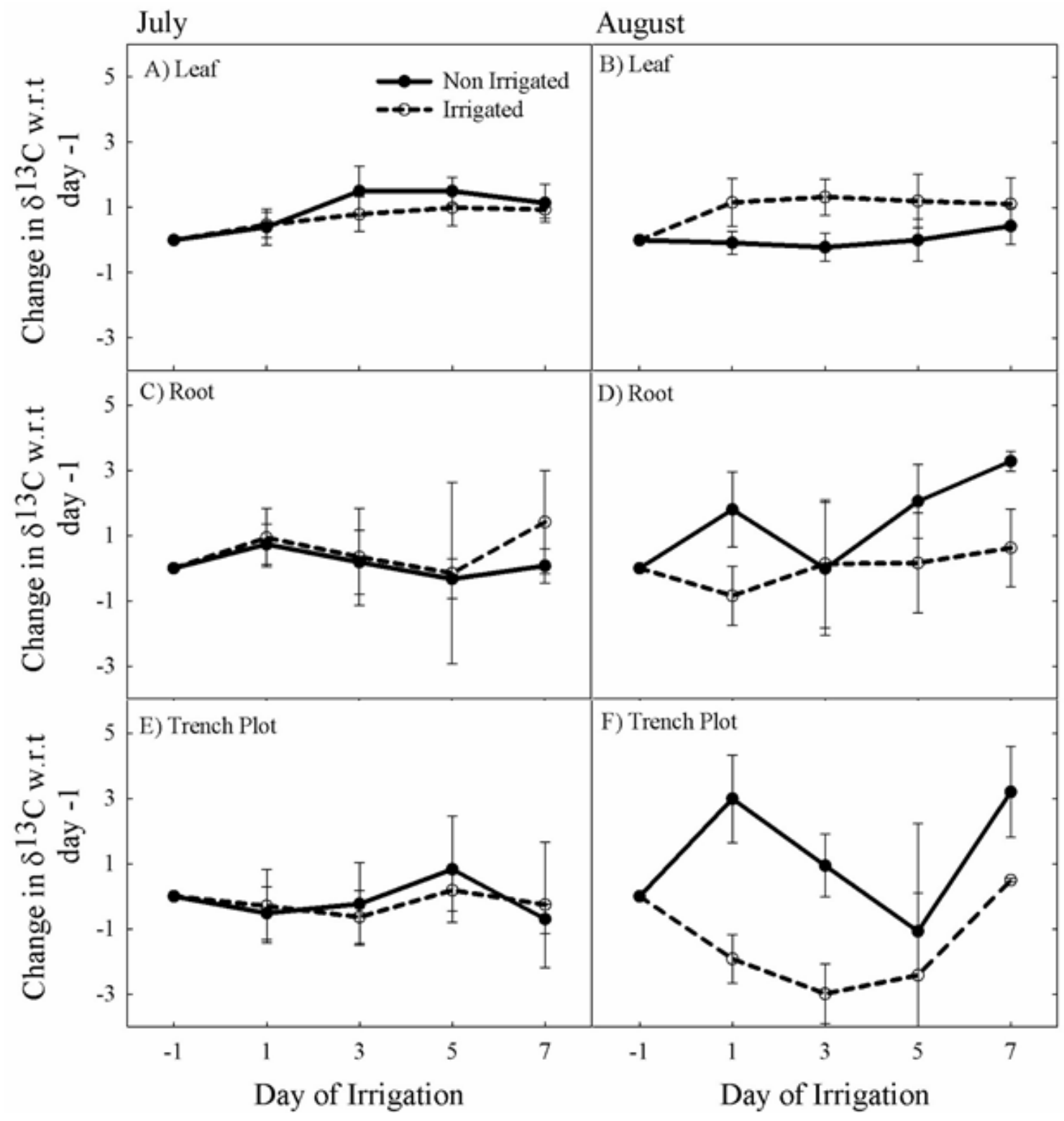

Figure 4: 


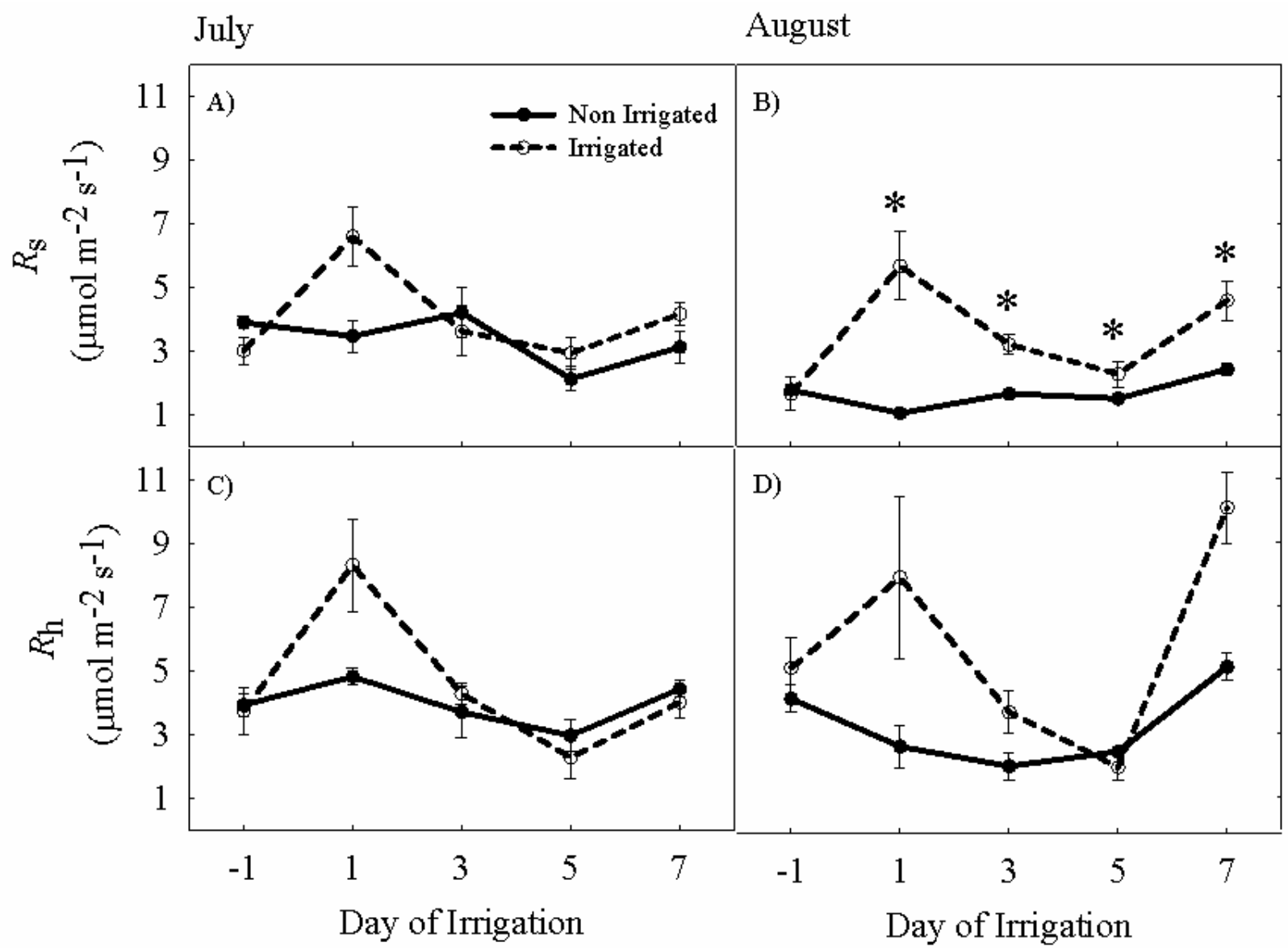

Figure 5: 


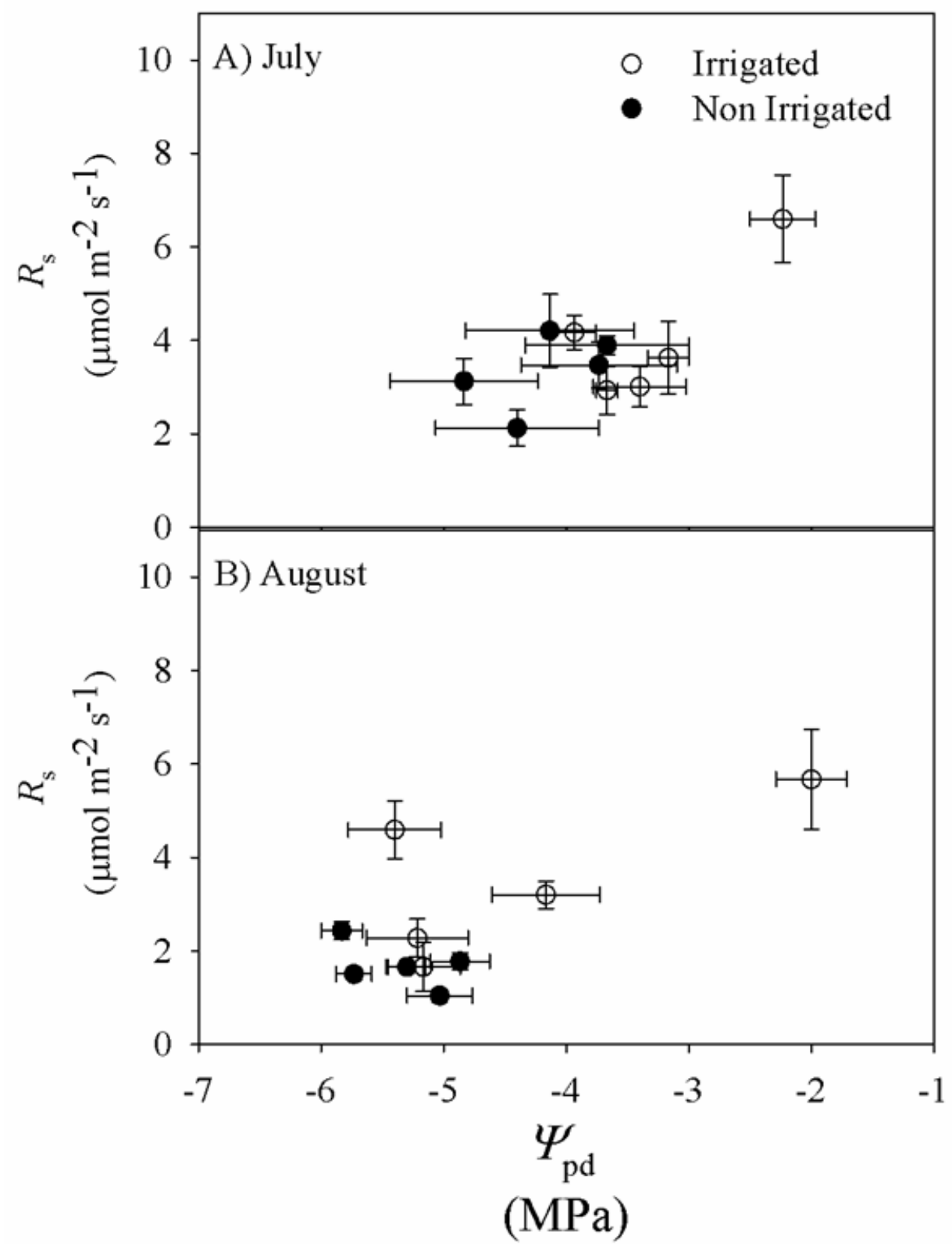

Figure 6: 

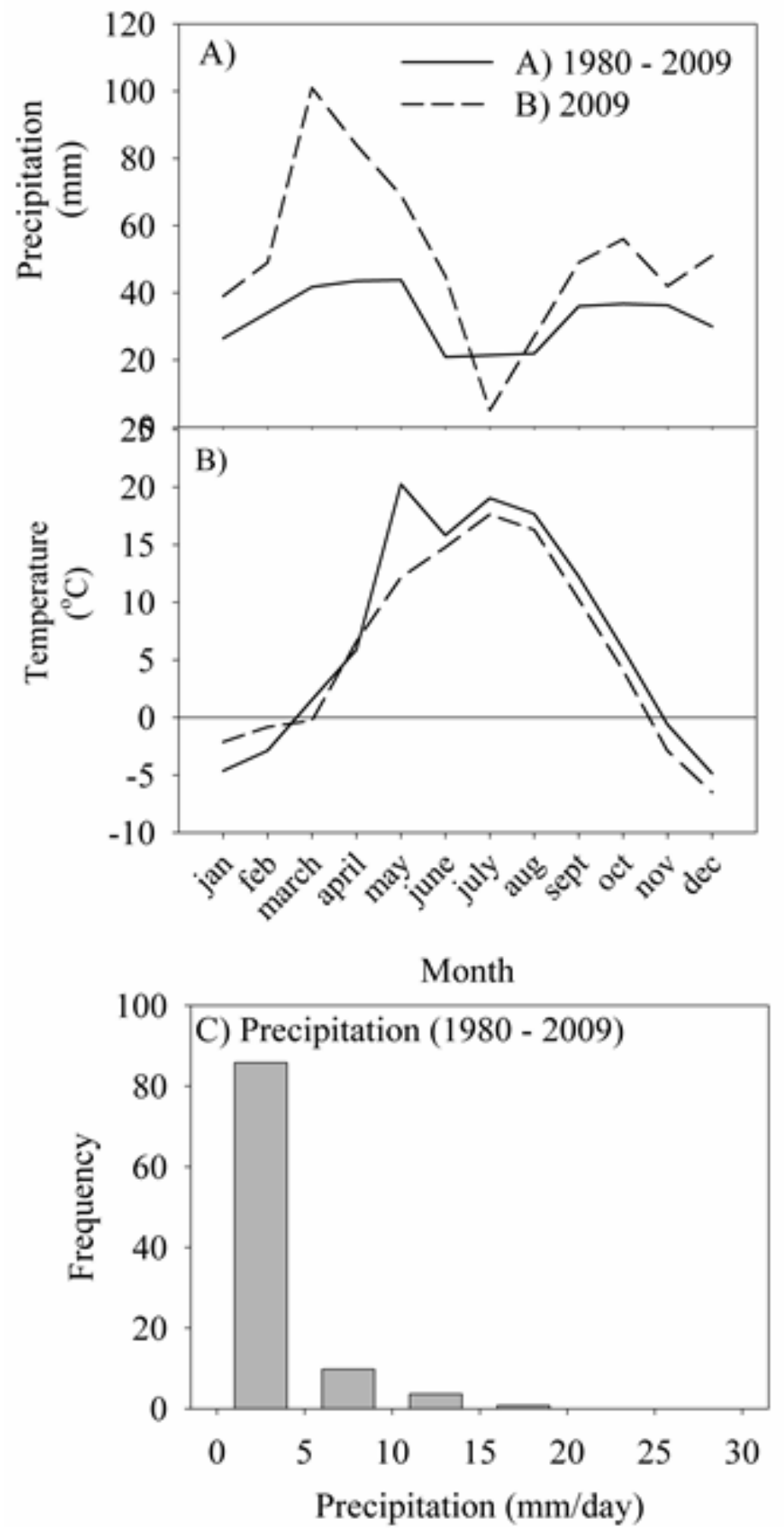

Appendix Figure A1 


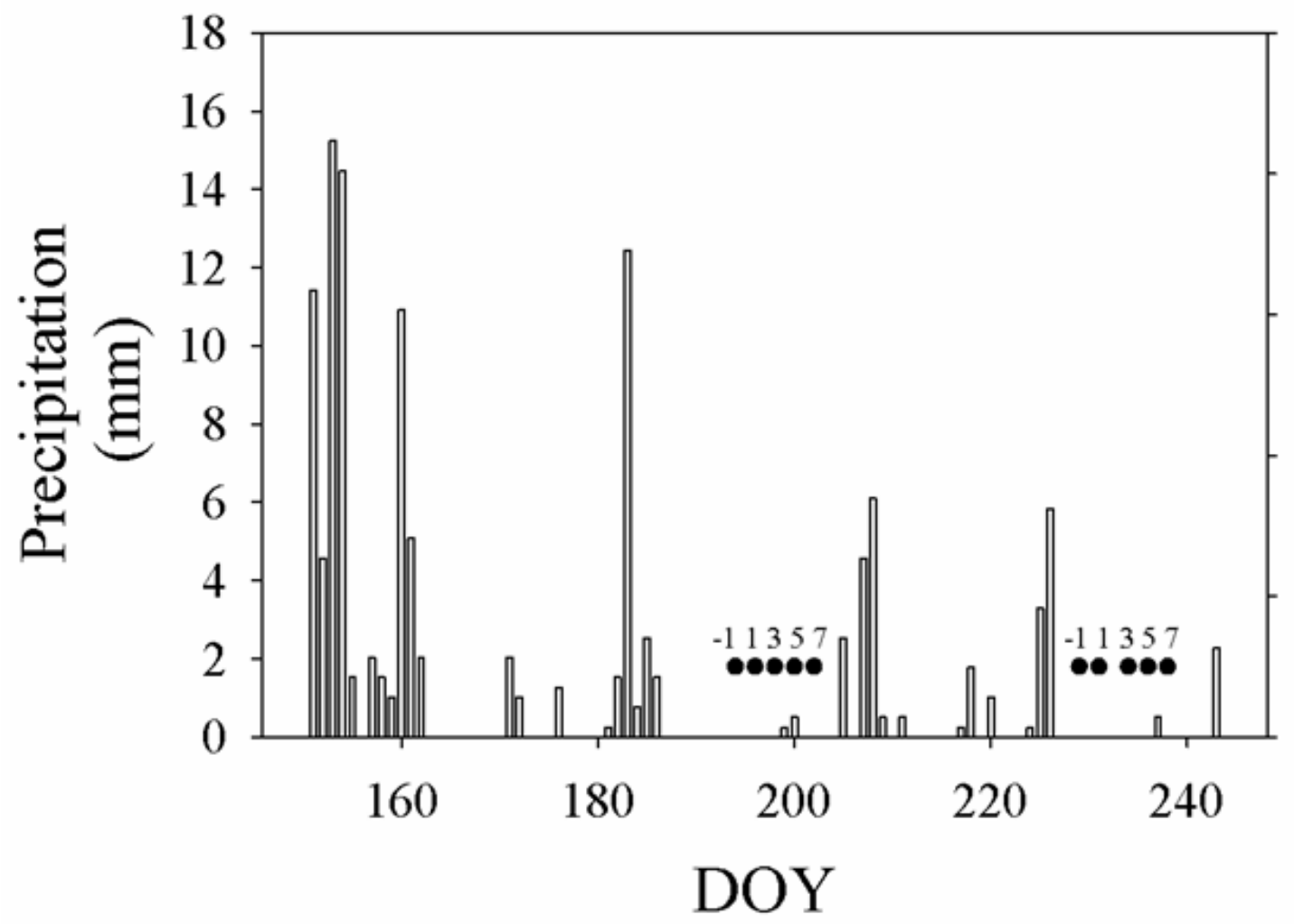

Appendix Figure A2: 